\title{
Nitrogen and Oxygen Isotope Signatures of Nitrogen Compounds during Anammox in the Laboratory and a Wastewater Treatment Plant
}

\author{
Shotoku Kotajima ${ }^{1}$, Keisuke Koba ${ }^{2,3 *}$, Daisuke Ikeda ${ }^{4}$, Akihiko Terada ${ }^{5,6}$, Kazuichi Isaka ${ }^{7,8}$, KazuYa Nishina ${ }^{9}$, \\ Yuuya Kimura ${ }^{7}$, Akiko Makabe ${ }^{3,10,11}$, Midori Yano ${ }^{1,2}$, Hirotsugu Fujitani ${ }^{12,13}$, Norisuke Ushiki ${ }^{12}$, Satoshi Tsuneda ${ }^{12}$, \\ and MUNEOKI YOH ${ }^{3}$ \\ ${ }^{1}$ Graduate School of Agriculture, Tokyo University of Agriculture and Technology, Tokyo, 1838509, Japan; ${ }^{2}$ Center for Ecological \\ Research, Kyoto University, Shiga, 5202113, Japan; ${ }^{3}$ Institute of Agriculture, Tokyo University of Agriculture and Technology, \\ Tokyo, 1838509, Japan; ${ }^{4}$ Graduate School of Engineering, Tokyo University of Agriculture and Technology, Tokyo, 1848588, \\ Japan; ${ }^{5}$ Department of Chemical Engineering, Tokyo University of Agriculture and Technology, Tokyo, 1848588, Japan; ${ }^{6}$ Institute \\ of Global Innovation Research, Tokyo University of Agriculture and Technology, Tokyo, 1858538, Japan; ${ }^{7}$ Hitachi, Ltd., Chiba, \\ 2710064, Japan; ${ }^{8}$ Department of Applied Chemistry, Faculty of Science and Engineering, Toyo University, Saitama, 3508585, \\ Japan; ${ }^{9}$ Center for Regional Environmental Research, National Institute of Environmental Sciences, Ibaraki, 3058506, Japan; \\ ${ }^{10}$ Project Team for Development of New-generation Research Protocol for Submarine Resources, Japan Agency for Marine-Earth \\ Science and Technology, Kanagawa, 2370061, Japan; ${ }^{11}$ Present address: Institute for Extra-cutting-edge Science and Technology \\ Avant-garde Research (X-star), Super-cutting-edge Grand and Advanced Research (SUGAR) Program, Japan Agency for Marine- \\ Earth Science and Technology, Kanagawa, 2370061, Japan; ${ }^{12}$ Department of Life Science and Medical Bioscience, Waseda \\ University, Tokyo, 1628480, Japan; and ${ }^{13}$ Present address: Department of Biological Sciences, Faculty of Science and \\ Engineering, Chuo University, Tokyo, 112-8551, Japan
}

(Received March 22, 2020-Accepted August 16, 2020_Published online November 7, 2020)

Isotopic fractionation factors against ${ }^{15} \mathrm{~N}$ and ${ }^{18} \mathrm{O}$ during anammox (anaerobic ammonia oxidization by nitrite) are critical for evaluating the importance of this process in natural environments. We performed batch incubation experiments with an anammox-dominated biomass to investigate nitrogen $(\mathrm{N})$ and oxygen $(\mathrm{O})$ isotopic fractionation factors during anammox and also examined apparent isotope fractionation factors during anammox in an actual wastewater treatment plant. We conducted one incubation experiment with high $\delta^{18} \mathrm{O}$ of water to investigate the effects of water $\delta^{18} \mathrm{O}$. The $\mathrm{N}$ isotopic fractionation factors estimated from incubation experiments and the wastewater treatment plant were similar to previous values. We also found that the $\mathrm{N}$ isotopic effect $\left({ }^{15} \varepsilon_{\mathrm{NXR}}\right.$ of -77.8 to $-65.9 \%$ and ${ }^{15} \Delta_{\mathrm{NXR}}$ of -31.3 to $-30.4 \%$ ) and possibly $\mathrm{O}$ isotopic effect $\left({ }^{18} \varepsilon_{\mathrm{NXR}}\right.$ of $-20.6 \%$ ) for anaerobic nitrite oxidation to nitrate were inverse. We applied the estimated isotopic fractionation factors to the ordinary differential equation model to clarify whether anammox induces deviations in the $\delta^{18} \mathrm{O}$ vs $\delta^{15} \mathrm{~N}$ of nitrate from a linear trajectory of 1 , similar to heterotrophic denitrification. Although this deviation has been attributed to nitrite oxidation, the $\mathrm{O}$ isotopic fractionation factor for anammox is crucial for obtaining a more detailed understanding of the mechanisms controlling this deviation. In our model, anammox induced the trajectory of the $\delta^{18} \mathrm{O}$ vs $\delta^{15} \mathrm{~N}$ of nitrate during denitrification to less than one, which strongly indicates that this deviation is evidence of nitrite oxidation by anammox under denitrifying conditions.

Key words: anammox, stable isotope, nitrite oxidation, isotopic fractionation, denitrification

Anammox (anaerobic ammonia oxidization by nitrite) has been intensively investigated since the discovery of its importance as a $\mathrm{N}$ removal process in natural ecosystems (Dalsgaard et al., 2003; Kuypers et al., 2003). The rates of anammox and denitrification are frequently similar (Kuypers et al., 2003; Hamersley et al., 2007; Lam et al., 2009). The detection of anammox in ecosystems is key for further investigations on the relative (quantitative) importance of anammox and denitrification to $\mathrm{N}$ losses. Molecular techniques, such as qPCR (Hamasaki et al., 2018) and bio-

* Corresponding author. E-mail: keikoba@ecology.kyoto-u.ac.jp; Tel: +81-77-549-8256; Fax: +81-77-549-8254.

Citation: Kotajima, S., Koba, K., Ikeda, D., Terada, A., Isaka, K., Nishina, K., et al. (2020) Nitrogen and Oxygen Isotope Signatures of Nitrogen Compounds during Anammox in the Laboratory and a Wastewater Treatment Plant. Microbes Environ 35: ME20031. https://doi.org/10.1264/jsme2.ME20031 marker analyses (ladderane lipids; Jaeschke et al., 2007), have generally been applied to detect anammox bacteria, followed by ${ }^{15} \mathrm{~N}$ tracer experiments (Amano et al., 2007) to assess anammox activities (rates) in the laboratory. Although this approach is promising, it only estimates potential anammox rates. Thus, it is crucial to develop screening techniques that estimate anammox in the field.

The naturally occurring stable isotope ratios of $\mathrm{N}\left({ }^{15} \mathrm{~N} /\right.$ ${ }^{14} \mathrm{~N}$, expressed as $\left.\delta^{15} \mathrm{~N}\right)$ and $\mathrm{O}\left({ }^{18} \mathrm{O} /{ }^{16} \mathrm{O}\right.$, expressed as $\left.\delta^{18} \mathrm{O}\right)$ are useful tracers for investigating the origins, transport, and biogeochemical processes of dissolved inorganic N (DIN), such as nitrate $\left(\mathrm{NO}_{3}^{-}\right)$, nitrite $\left(\mathrm{NO}_{2}^{-}\right)$, and ammonium $\left(\mathrm{NH}_{4}^{+}\right)$, in ecosystems (Casciotti, 2016a, 2016b; Denk et al., 2017; Thuan et al., 2018). Regarding the use of $\delta^{15} \mathrm{~N}$ and $\delta^{18} \mathrm{O}$ to interpret the complex dynamics of DIN, it is essential to apply the isotopic fractionation factors of specific reactions of DIN production and consumption. Previous studies on heterotrophic denitrification estimated ${ }^{15} \mathrm{~N}$ 
(Blackmer and Bremner, 1977; Chien et al., 1977; Mariotti et al., 1981, 1982; Bryan et al., 1983; Kawanishi et al., 1993; Barford et al., 2017) and ${ }^{18} \mathrm{O}$ fractionation factors (Böttcher et al., 1990; Granger et al., 2008; Kritee et al., 2012; Frey et al., 2014; Martin and Casciotti, 2016; Osaka et al., 2018; Wang et al., 2018). Detailed information on isotopic fractionation during denitrification has encouraged the use of the $\delta^{15} \mathrm{~N}$ and $\delta^{18} \mathrm{O}$ of $\mathrm{NO}_{3}^{-}$in investigations on the occurrence and magnitude of denitrification in many ecosystems (Mariotti et al., 1988; Koba et al., 1997; Ostrom et al., 2002; Lehmann et al., 2003; Sigman et al., 2003; Houlton et al., 2006; Houlton and Bai, 2009; Miyajima et al., 2009; Fang et al., 2015; Lennon and Houlton, 2017).

In contrast to denitrification, few studies have used the $\delta^{15} \mathrm{~N}$ and $\delta^{18} \mathrm{O}$ of DIN to examine anammox (Prokopenko et al., 2006; Prokopenko et al., 2013; Wenk et al., 2014; Dähnke and Thamdrup, 2016), and only two studies (Brunner et al., 2013; Kobayashi et al., 2019) have reported isotopic fractionation factors for the anammox reaction. These factors must be known in order to estimate the importance of anammox in a studied ecosystem with the $\delta^{15} \mathrm{~N}$ and $\delta^{18} \mathrm{O}$ of DIN. Brunner et al. (2013) estimated a large inverse $\mathrm{N}$ isotope effect (i.e., the heavier isotope, ${ }^{15} \mathrm{~N}$, reacts faster than the lighter isotope, ${ }^{14} \mathrm{~N}$ ) during $\mathrm{NO}_{3}^{-}$production (by anaerobic nitrite oxidation) in anammox as well as a large normal (i.e., the lighter ${ }^{14} \mathrm{~N}$ reacts faster than the heavier ${ }^{15} \mathrm{~N}$ ) isotope effect for ammonium oxidation, which was confirmed in a later study by Kobayashi et al. (2019). However, they only reported the combined ${ }^{18} \mathrm{O}$ isotope fractionation factors and do not provide the isotope fractionation factors for the $\mathrm{NO}_{2}^{-}$oxidation and its relevant oxygen atom incorporation from water, involved in the combined factors.

Studies on ${ }^{15} \mathrm{~N}$ and ${ }^{18} \mathrm{O}$ fractionation factors revealed that $\mathrm{NO}_{3}^{-}$consumption (the assimilatory and dissimilatory reduction of $\mathrm{NO}_{3}^{-}$) generally induced a 1:1 increase in the $\delta^{18} \mathrm{O}$ and $\delta^{15} \mathrm{~N}$ of $\mathrm{NO}_{3}^{-}$(Granger et al., 2008; Granger et al., 2010; Karsh et al., 2012; Rohde et al., 2015; Osaka et al., 2018). This finding prompted the use of the $\delta^{18} \mathrm{O}$ and $\delta^{15} \mathrm{~N}$ of $\mathrm{NO}_{3}{ }^{-}$to detect $\mathrm{NO}_{3}^{-}$consumption in the actual ecosystem as well as investigations on $\mathrm{NO}_{3}{ }^{-}$isotope anomalies, specifically isotopic deviations from a slope of 1 in the $\delta^{18} \mathrm{O}$ vs $\delta^{15} \mathrm{~N}$ of $\mathrm{NO}_{3}^{-}(\Delta[15,18]$; Sigman et al., 2005), in order to deepen insights into $\mathrm{NO}_{3}{ }^{-}$dynamics (Casciotti et al., 2008; Casciotti and Buchwald, 2012; Bourbonnais et al., 2013; Peters et al., 2018; White et al., 2019). Granger and Wankel (2016) proposed that widely observed deviations in the $\delta^{18} \mathrm{O}$ vs $\delta^{15} \mathrm{~N}$ of $\mathrm{NO}_{3}^{-}$from the denitrification slope of 1 in freshwater systems (Sigman et al., 2005; Granger et al., 2008; Kritee et al., 2012) must result from concurrent $\mathrm{NO}_{3}^{-}$production (nitrification or anammox) in the denitrifying system that has been largely overlooked. However, they lacked information on the ${ }^{18} \mathrm{O}$ fractionation factor for anammox, and assumed that the ${ }^{18} \mathrm{O}$ fractionation factor during $\mathrm{NO}_{3}{ }^{-}$ production by anammox was similar to that for aerobic nitrite oxidation to $\mathrm{NO}_{3}{ }^{-}$by nitrifiers (nitrification). Thus, it is essential to investigate the ${ }^{15} \mathrm{~N}$ and ${ }^{18} \mathrm{O}$ fractionation factors during anammox not only for the better use of the $\delta^{18} \mathrm{O}$ and $\delta^{15} \mathrm{~N}$ of $\mathrm{NO}_{3}^{-}$in anammox studies, but also to obtain a more detailed understanding of ${ }^{15} \mathrm{~N}$ and ${ }^{18} \mathrm{O}$ fractionation.

We herein report unique data on ${ }^{18} \mathrm{O}$ fractionation factors during anammox. We calculated apparent ${ }^{15} \mathrm{~N}$ and ${ }^{18} \mathrm{O}$ fractionation factors with data collected from a wastewater treatment plant (WWTP) at which anammox reactors were installed at the final stage of treatment (Isaka et al., 2017). We also performed anaerobic laboratory incubations with an anammox-dominated biomass to obtain more information on isotopic fractionation during anammox. We conducted one incubation experiment with high $\delta^{18} \mathrm{O}$ of water to investigate the effects of water $\delta^{18} \mathrm{O}$. We then simulated system behavior with the observed isotopic fractionation factors to establish whether deviations in the $\delta^{18} \mathrm{O}$ vs $\delta^{15} \mathrm{~N}$ of $\mathrm{NO}_{3}{ }^{-}$ from the denitrification slope of 1 may be used to detect anammox activity.

\section{Materials and Methods}

\section{Full-scale anammox wastewater treatment plant}

Influent and treated water in the full-scale anammox wastewater treatment plant (Isaka et al., 2017) were sampled three times (28th April, 7th and 12th May 2015). Detailed information on water chemistry and plant performance have been reported by Isaka et al. (2017). The anammox plant consists of a denitrifier reactor (DN), biochemical oxygen demand (BOD) oxidation reactor (BD), nitrite-nitrification reactor (NT), and anammox reactor (ANX). We collected water samples from each reactor (Fig. S1). The wastewater introduced into this anammox plant was effluent from an ammonia plant, which was pure water containing mainly $\mathrm{NH}_{4}^{+}$and methanol. Average $\mathrm{NH}_{4}{ }^{+}$and total organic concentrations were 658 and $37 \mathrm{mg} \mathrm{L}^{-1}$, respectively (Isaka et al., 2017). Solutions were sampled from these reactors (Fig. S1) to measure the concentrations and isotope ratios of DIN. Samples (10 mL each) were immediately filtered through $0.45-\mu \mathrm{m}$ disk filters (25CS045AN; ADVANTEC Toyo Kaisha) and then collected in plastic centrifuge tubes. Samples were frozen until further measurements.

\section{Biomass incubation experiments}

We performed batch incubations with anammox bacteria. Details on a small-scale anammox reactor with activated sludge, including start-up information, maintenance, performance, input solutions, and microbial communities of the reactor, are provided in Supplemental Information (SI Text 1.1).

In the first experiment (Experiment A), the biomass in the reactor was sampled and incubated with the media used for the reactor, while the sampled biomass was re-suspended in fresh, chemically defined media in the second (Experiment B) and third (Experiment C) experiments. Difficulties were associated with performing incubation experiments with the anammox biomass for isotopic measurements, and, thus, we employed slightly different settings and operations to facilitate constant and active anammox reactions. In each experiment, $15 \mathrm{~mL}$ of the biomass suspension in media solution was filtered with filter paper (Reeve Angel, Whatman) and differences in filter weights before and after filtration were used to calculate the suspended solid (S.S.) concentration after the filter had been oven-dried (at $\left.105^{\circ} \mathrm{C}\right)$.

\section{Experiment $A$}

The biofilm and incubation media solution $(500 \mathrm{~mL}$ in total) were sampled from the incubation membrane in the anammox reactor (SI Text 1.1). The incubation was performed anaerobically in the glovebox at room temperature $\left(25-30^{\circ} \mathrm{C}\right)$ after the purging of media by $\mathrm{N}_{2}$ gas to remove dissolved oxygen (DO). $\mathrm{pH}, \mathrm{DO}$, and the concentrations of $\mathrm{NH}_{4}^{+}$and $\mathrm{NO}_{2}^{-}$were regularly measured to confirm the anammox activity of the biofilm, and $\mathrm{pH}(8.0)$ was maintained by adding $\mathrm{KH}_{2} \mathrm{PO}_{4}$ and $\mathrm{Na}_{2} \mathrm{HPO}_{4} \cdot 12 \mathrm{H}_{2} \mathrm{O}$ solution. After the addition of $\mathrm{NaNO}_{2},\left(\mathrm{NH}_{4}\right)_{2} \mathrm{SO}_{4}$, and $\mathrm{NaHCO}_{3}$, we started the incubation and sampled $10 \mathrm{~mL}$ of media. Sampled media were 
filtered with a $0.20-\mu \mathrm{m}$ syringe filter and then split into three; one for $\mathrm{NO}_{3}{ }^{-}$followed by the removal of $\mathrm{NO}_{2}^{-}$(Granger and Sigman, 2009), another one for $\mathrm{NO}_{2}^{-}$with high $\mathrm{pH}$ by the addition of $2 \mathrm{M}$ $\mathrm{NaOH}$ solution to prevent oxygen atom exchange between $\mathrm{NO}_{2}^{-}$and water (Bourbonnais et al., 2017), and one for $\mathrm{NH}_{4}^{+}$with low $\mathrm{pH}$ by the addition of $4.8 \mathrm{M} \mathrm{H}_{2} \mathrm{SO}_{4}$ to prevent $\mathrm{NH}_{4}^{+}$from volatilizing. These subsamples were frozen $\left(-30^{\circ} \mathrm{C}\right)$ until further analyses.

\section{Experiment B}

The granule biomass that accumulated at the bottom of the anammox reactor was sampled. Granules were rinsed anaerobically with new media ( $\mathrm{N}_{2}$ purged) in the glovebox. Media consisted of $\mathrm{NaHCO}_{3} 502 \mathrm{mg} \mathrm{L}{ }^{-1} ; \mathrm{MgSO}_{4} \cdot 7 \mathrm{H}_{2} \mathrm{O} 603 \mathrm{mg} \mathrm{L}{ }^{-1} ; \mathrm{CaCl}_{2} 180.5 \mathrm{mg}$ $\mathrm{L}^{-1} ; \mathrm{KH}_{2} \mathrm{PO}_{4} 169 \mathrm{mg} \mathrm{L}{ }^{-1} ; \mathrm{Na}_{2} \mathrm{HPO}_{4} \cdot 12 \mathrm{H}_{2} \mathrm{O} 282 \mathrm{mg} \mathrm{L}{ }^{-1}$; trace elements of solution I (containing EDTA $6.369 \mathrm{~g} \mathrm{~L}^{-1} ; \mathrm{FeSO}_{4} \cdot 7 \mathrm{H}_{2} \mathrm{O}$ $9.14 \mathrm{~g} \mathrm{~L}^{-1}$ ) $0.5 \mathrm{~mL}$ and solution II (containing EDTA $19.106 \mathrm{~g} \mathrm{~L}^{-1}$; $\mathrm{ZnSO}_{4} \cdot 7 \mathrm{H}_{2} \mathrm{O} 0.43 \mathrm{~g} \mathrm{~L}^{-1} ; \mathrm{CoCl}_{2} \cdot 6 \mathrm{H}_{2} \mathrm{O} 0.24 \mathrm{~g} \mathrm{~L}^{-1} ; \mathrm{MnCl}_{2} \cdot 4 \mathrm{H}_{2} \mathrm{O}$ $0.99 \mathrm{~g} \mathrm{~L}^{-1} ; \mathrm{CuSO}_{4} \cdot 5 \mathrm{H}_{2} \mathrm{O} 0.25 \mathrm{~g} \mathrm{~L}^{-1} ; \mathrm{Na}_{2} \mathrm{MoO}_{4} \cdot 2 \mathrm{H}_{2} \mathrm{O} 0.22 \mathrm{~g} \mathrm{~L}^{-1}$; $\mathrm{NiCl}_{2} \cdot 6 \mathrm{H}_{2} \mathrm{O} 0.19 \mathrm{~g} \mathrm{~L}^{-1} ; \mathrm{Na}_{2} \mathrm{SeO}_{4} \cdot 10 \mathrm{H}_{2} \mathrm{O} 0.21 \mathrm{~g} \mathrm{~L}^{-1} ; \mathrm{H}_{3} \mathrm{BO}_{3} 0.014 \mathrm{~g}$ $\left.\mathrm{L}^{-1}\right) 0.5 \mathrm{~mL}$. We added $\mathrm{NaNO}_{2}$ and $\left(\mathrm{NH}_{4}\right)_{2} \mathrm{SO}_{4}$ to media $(500 \mathrm{~mL})$ with the anammox granules and then started the incubation at room temperature $\left(25-30^{\circ} \mathrm{C}\right)$. We monitored $\mathrm{pH}(7.9$ to 8.8$)$ and $\mathrm{NO}_{2}{ }^{-}$to assess the progress of anammox. Sampling was performed as described in Experiment A.

\section{Experiment $C$}

We incubated the biofilm collected from the incubation membrane in the anammox reactor with the same media used in Experiment $\mathrm{B}$; however, the $\delta^{18} \mathrm{O}$ of water $\left(\delta^{18} \mathrm{O}_{\mathrm{H} 2 \mathrm{O}}\right)$ was markedly higher $(229 \%)$ than that in Experiments A and B (-8\%). This "heavy" water was prepared by mixing ${ }^{18} \mathrm{O}$-labeled water $\left(10 \%\right.$ atom $\left.{ }^{18} \mathrm{O}\right)$ with Milli-Q water. During the incubation, media with biofilms were shaken at a constant temperature $\left(30^{\circ} \mathrm{C}\right)$ and continuously purged with a gas mixture $\left(95 \% \mathrm{Ar}+5 \% \mathrm{CO}_{2}\right)$ to maintain low DO levels. $\mathrm{pH}$ ranged between 7.1 and 7.5 and the monitoring and sampling scheme was identical to Experiment B

\section{Chemical analysis}

DIN concentrations in water samples from the anammox plant and incubation experiments were measured using colorimetric methods with an autoanalyzer (Quatro, BL-Tec) (Thuan et al., 2018) after appropriate dilutions. In Experiment $\mathrm{A}, \mathrm{NH}_{4}{ }^{+}$concentrations were measured during the incubation by the $\mathrm{o}-$ phthaldialdehyde (OPA) method (Holmes et al., 1999). The DO and $\mathrm{pH}$ of the incubation media were monitored during the incubation with a DO meter (HQ30d; Hach) and $\mathrm{pH}$ meter (D-71; Horiba).

$\delta^{15} \mathrm{~N}$ and $\delta^{18} \mathrm{O}$ values were assessed by GC-IRMS (Sercon 20-22 with Cryoprep) (Thuan et al., 2018) with the denitrifier method (Sigman et al., 2001; Casciotti et al., 2002) for $\mathrm{NO}_{3}^{-}\left(\delta^{15} \mathrm{~N}_{\mathrm{NO} 3-}\right.$ and $\delta^{18} \mathrm{O}_{\mathrm{NO} 3-}$, respectively) with USGS $32,34,35$, and IAEA-2 as standards, and with the azide method (McIlvin and Altabet, 2005) for $\mathrm{NO}_{2}^{-}\left(\delta^{15} \mathrm{~N}_{\mathrm{NO2} 2}\right.$ and $\delta^{18} \mathrm{O}_{\mathrm{NO} 2}$, respectively) with TUAT-NO2-1 to TUAT-NO2-5 (Thuan et al., 2018) calibrated against $\mathrm{N}-23$, N-7373, and N-10219 (Casciotti et al., 2007) as the standards. Analytical precision (expressed as the standard deviation of repeatedly measured samples) was $\pm 0.2 \%$ for $\delta^{15} \mathrm{~N}_{\mathrm{NO2}-}$ and $\delta^{15} \mathrm{~N}_{\mathrm{NO} 3-}$, and $\pm 0.5 \%$ for $\delta^{18} \mathrm{O}_{\mathrm{NO} 2-}$ and $\delta^{18} \mathrm{O}_{\mathrm{NO} 3}$. The $\delta^{15} \mathrm{~N}$ values of $\mathrm{NH}_{4}{ }^{+}$ $\left(\delta^{15} \mathrm{~N}_{\mathrm{NH} 4+}\right)$ were evaluated using GC-IRMS with the denitrifier method after the conversion of $\mathrm{NH}_{4}{ }^{+}$to $\mathrm{NO}_{3}{ }^{-}$by persulfate oxidation (Koba et al., 2012; Thuan et al., 2018) with USGS 25, 26, and IAEA-N-2 as the standards. Analytical precision was $\pm 0.5 \%$ o for the $\delta^{15} \mathrm{~N}$ of $\mathrm{NH}_{4}^{+}$. Water with high $\delta^{18} \mathrm{O}(229 \%$; measured by GCIRMS with the modified azide method; McIlvin and Casciotti, 2006; Thuan et al., 2018) from Experiment $\mathrm{C}$ was used to prepare $\mathrm{NO}_{3}{ }^{-}$and $\mathrm{NO}_{2}{ }^{-}$isotope standards for $\mathrm{NO}_{3}{ }^{-}$and $\mathrm{NO}_{2}{ }^{-}$measurements in order to correct for the effects of oxygen atom incorporation during the analysis. $\delta^{15} \mathrm{~N}$ and $\delta^{18} \mathrm{O}$ are expressed as (R_SampleN/ R_Nitrogen)-1 and (R_SampleO/R_Oxygen)-1 where R_SampleN and R_SampleO are $\left[{ }^{15} \mathrm{~N} /{ }^{14} \mathrm{~N}\right]$ and $\left[{ }^{18} \mathrm{O} /{ }^{16} \mathrm{O}\right]$ of the sample, respectively, R_Nitrogen is $\left[{ }^{15} \mathrm{~N} /{ }^{14} \mathrm{~N}\right]$ of atmospheric $\mathrm{N}_{2}$ and R_Oxygen is $\left[{ }^{18} \mathrm{O} /{ }^{16} \mathrm{O}\right]$ of Vienna Standard Mean Ocean Water (Table $\mathrm{S} 1$ ).

Calculation of apparent isotopic fractionation factors for the anammox plant

Apparent isotopic fractionation factors regarding anammox in the anammox plant were calculated as described by Kobayashi et al. (2019) based on steady-state, open-system isotope systematics reported by Fry (2006).

Apparent $N$ isotope effects of the ammonium oxidation to $N_{2}$, and nitrite reduction and oxidation for the anammox plant

The ammonium oxidation to $\mathrm{N}_{2}$ by $\mathrm{NO}_{2}^{-}$has isotope fractionation defined as ${ }^{15} \Delta_{\mathrm{AMX}}$. The $\delta^{15} \mathrm{~N}$ of influx $\mathrm{NH}_{4}^{+}\left(\delta^{15} \mathrm{~N}_{\mathrm{NH} 4+} \mathrm{NT}\right)$, residual $\mathrm{NH}_{4}^{+}\left(\delta^{15} \mathrm{~N}_{\mathrm{NH} 4+}{ }_{\mathrm{ANX}}\right)$, and the fraction of $\mathrm{NH}_{4}^{+}$reacting $\left(f_{\mathrm{NH}_{4}}\right)$ in ANX reactor (Fig. S1) at a steady state are used to estimate ${ }^{15} \Delta_{\mathrm{AMX}}$ (Fry, 2006; Kobayashi et al., 2019):

$$
\begin{aligned}
& { }^{15} \Delta_{\mathrm{AMX}}=\left(\delta^{15} \mathrm{~N}_{\mathrm{NH} 4+-\mathrm{ANX}}-\delta^{15} \mathrm{~N}_{\mathrm{NH} 4+} \mathrm{NT}\right) / f_{\mathrm{NH4+}}--- \text { eq. }(1) \\
& f_{N H 4+}=\left(\left[\mathrm{NH}_{4}^{+}\right]_{\mathrm{NT}}-\left[\mathrm{NH}_{4}^{+}\right]_{\mathrm{ANX}}\right) /\left[\mathrm{NH}_{4}^{+}\right]_{\mathrm{NT}}
\end{aligned}
$$

where $\left[\mathrm{NH}_{4}^{+}\right]_{\mathrm{NT}}$ and $\left[\mathrm{NH}_{4}^{+}\right]_{\mathrm{ANX}}$ are the $\mathrm{NH}_{4}^{+}$concentrations in NT and ANX reactors, respectively.

The $\delta^{15} \mathrm{~N}_{\text {of }} \mathrm{NO}_{2}^{-}, \mathrm{NO}_{3}^{-}$, and $\mathrm{N}_{2}$ in ANX reactor $\left(\delta^{15} \mathrm{~N}_{\mathrm{NO2}-} \mathrm{ANX}\right.$, $\delta^{15} \mathrm{~N}_{\mathrm{NO} 3-\mathrm{ANX}}$, and $\delta^{15} \mathrm{~N}_{\mathrm{N} 2 \text { ANX }}$, respectively) at the steady state are given as follows (Fry, 2006; Kobayashi et al., 2019):

$$
\begin{aligned}
& { }^{15} \Delta_{\mathrm{AMXNIR}}=\delta^{15} \mathrm{~N}_{\mathrm{NO} 2-\_\mathrm{ANX}}-\delta^{15} \mathrm{~N}_{\mathrm{N} 2 \_\mathrm{ANX}}{ }--- \text { eq. (2) } \\
& { }^{15} \Delta_{\mathrm{NXR}}=\delta^{15} \mathrm{~N}_{\mathrm{NO} 2 \text { __ANX }}-\delta^{15} \mathrm{~N}_{\mathrm{NO} 3 \text { __ANX }}{ }^{---} \text {eq. (3) }
\end{aligned}
$$

where ${ }^{15} \mathrm{~N}$ fractionation for nitrite reduction in anammox and nitrite oxidation are ${ }^{15} \Delta_{\text {AMXNIR }}$ and ${ }^{15} \Delta_{\mathrm{NXR}}$, respectively.

$\delta^{15} \mathrm{~N}_{\mathrm{NO2}-\mathrm{NT}}$ is defined as:

$$
\begin{aligned}
\delta^{15} \mathrm{~N}_{\mathrm{NO2}-\mathrm{NT}}= & (1-a-b) \times \delta^{15} \mathrm{~N}_{\mathrm{N2} \_\mathrm{ANX}}+a \times \delta^{15} \mathrm{~N}_{\mathrm{NO2} \text { _ANX }}+b \\
\times & \delta^{15} \mathrm{~N}_{\mathrm{NO} 3 \text { __ANX }}--- \text { eq. }(4)
\end{aligned}
$$

with

$$
\begin{aligned}
& a=\left[\mathrm{NO}_{2}^{-}\right]_{\mathrm{ANX}} /\left(\left[\mathrm{NO}_{2}^{-}\right]_{\mathrm{NT}}-\left[\mathrm{NO}_{2}^{-}\right]_{\mathrm{ANX}}\right) \\
& b=\left(\left[\mathrm{NO}_{3}^{-}\right]_{\mathrm{ANX}}-\left[\mathrm{NO}_{3}^{-}\right]_{\mathrm{NT}}\right) /\left(\left[\mathrm{NO}_{2}^{-}\right]_{\mathrm{NT}}-\left[\mathrm{NO}_{2}^{-}\right]_{\mathrm{ANX}}\right)
\end{aligned}
$$

where $\delta^{15} \mathrm{~N}_{\mathrm{NO} 2-\mathrm{NT}}$ is $\delta^{15} \mathrm{~N}_{\mathrm{NO2}-}$ in NT reactor and the concentrations of $\mathrm{NO}_{2}^{-}$and $\mathrm{NO}_{3}^{-}$in $\mathrm{NT}$ and $\mathrm{ANX}$ reactors are $\left[\mathrm{NO}_{2}^{-}\right]_{\mathrm{NT}}$, $\left[\mathrm{NO}_{2}^{-}\right]_{\mathrm{ANX}},\left[\mathrm{NO}_{3}^{-}\right]_{\mathrm{NT}}$, and $\left[\mathrm{NO}_{3}^{-}\right]_{\mathrm{ANX}}$, respectively.

The combination of eqs. (2) and (4) gives

$$
\begin{aligned}
& \delta^{15} \mathrm{~N}_{\mathrm{NO2} \_\mathrm{NT}}=(1-a-b) \times \delta^{15} \mathrm{~N}_{\mathrm{N} 2 \_\mathrm{ANX}}+a \times \delta^{15} \mathrm{~N}_{\mathrm{NO2} \_ \text {_ANX }}+b \\
& \times \delta^{15} \mathrm{~N}_{\mathrm{NO} 3-\mathrm{ANX}} \\
& =(1-a-b) \times\left(\delta^{15} \mathrm{~N}_{\mathrm{NO} 2-\mathrm{ANX}}-{ }^{15} \Delta_{\mathrm{AMXNIR}}\right)+a \\
& \times \delta^{15} \mathrm{~N}_{\mathrm{NO2}-\mathrm{ANX}}+b \times \delta^{15} \mathrm{~N}_{\mathrm{NO} 3-\mathrm{ANX}} \\
& =\delta^{15} \mathrm{~N}_{\mathrm{NO} 2-\mathrm{ANX}}-{ }^{15} \Delta_{\mathrm{AMXNIR}}-a \times \delta^{15} \mathrm{~N}_{\mathrm{NO2}-\mathrm{ANX}} \\
& +a \times{ }^{15} \bar{\Delta}_{\mathrm{AMXNIR}}-b \times \delta^{15} \mathrm{~N}_{\mathrm{NO} 2-\mathrm{ANX}}+b \times{ }^{15} \Delta_{\mathrm{AMXNIR}} \\
& +a \times \delta^{15} \mathrm{~N}_{\mathrm{NO} 2-\mathrm{ANX}}+b \times \delta^{15} \mathrm{~N}_{\mathrm{NO} 3-\mathrm{ANX}}^{-} \\
& =b \times\left(\delta^{15} \mathrm{~N}_{\mathrm{NO} 3-\mathrm{ANX}}-\delta^{15} \mathrm{~N}_{\mathrm{NO} 2-\mathrm{ANX}}\right)+\delta^{15} \mathrm{~N}_{\mathrm{NO} 2-\mathrm{ANX}} \\
& +{ }^{15} \Delta_{\mathrm{AMXNIR}} \times(a+b-1) \\
& =-\left(b \times{ }^{15} \Delta_{\mathrm{NXR}}\right)+\delta^{15} \mathrm{~N}_{\mathrm{NO} 2-\mathrm{ANX}}+{ }^{15} \Delta_{\mathrm{AMXNIR}} \times(a+b-1) \\
& { }^{15} \Delta_{\mathrm{AMXNIR}}=\left[\delta^{15} \mathrm{~N}_{\mathrm{NO2}-\mathrm{ANX}}-\delta^{15} \mathrm{~N}_{\mathrm{NO2}-\mathrm{NT}}-b \times{ }^{15} \Delta_{\mathrm{NXR}}\right] /(a+b-1) \\
& \text {--- eq. (5) }
\end{aligned}
$$

Apparent combined $O$ isotope effect of nitrite oxidation for the anammox plant

To calculate ${ }^{18} \mathrm{O}$ fractionation during nitrite oxidation to nitrate, we followed the approach described by Kobayashi et al. (2019) to calculate combined isotope fractionation $\left({ }^{18} \mathrm{E}_{\mathrm{AMXcombined}}\right)$ because of the lack of detailed information on isotopic fractionation for the nitrite oxidation and oxygen atom incorporation during nitrite oxi- 
dation. Thus, we calculated ${ }^{18} \mathrm{E}_{\mathrm{AMXcombined}}$ as follows:

$$
\begin{aligned}
& { }^{18} \mathrm{E}_{\mathrm{AMX} \text { combined }}=2 / 3 \delta^{18} \mathrm{O}_{\mathrm{NO2}-\mathrm{ANX}}+1 / 3 \delta^{18} \mathrm{O}_{\mathrm{H} 2 \mathrm{O}}-\delta^{18} \mathrm{O}_{\mathrm{NO} 3-\_\mathrm{ANX}} \\
& \text {--- eq. (6) }
\end{aligned}
$$

where $\delta^{18} \mathrm{O}_{\mathrm{NO} 2 \text { - ANX }}, \delta^{18} \mathrm{O}_{\mathrm{H} 2 \mathrm{O}}$, and $\delta^{18} \mathrm{O}_{\mathrm{NO} 3-\text { ANX }}$ are the ${ }^{18} \mathrm{O}$ ratios of $\mathrm{NO}_{2}^{-}$, water, and $\mathrm{NO}_{3}^{-}$in ANX reactor, respectively.

Calculation of isotopic fractionation factors for incubations and a simulation with the dynamic model (the anammox model)

We developed an ordinary differential equation model as described by Casciotti and Buchwald (2012), Granger and Wankel (2016), and He and Bao (2019). We prepared the model (the anammox model) to calculate the isotopic fractionation factors for Experiments $\mathrm{A}, \mathrm{B}$, and $\mathrm{C}$. The $\mathrm{N}$ transformations and associated isotopic fractionation (Fig. 1) were implemented in the anammox model with Berkeley Madonna (BM) software (Macey et al., 2000), with a 4th-order Runge-Kutta method for integration. We initially used the curve-fitting function in BM software (least squares fitting) to calculate the rate constant of the ammonium oxidation based on concentration data in each experiment. Isotopic fractionation factors and the exchange rate of oxygen atoms between water and $\mathrm{NO}_{2}^{-}$were then estimated from isotopic data.

Fluxes regarding the anammox process (Fig. 1) are defined as

$$
\begin{aligned}
& \mathrm{AMX}=\mathrm{AMXNIR}=k_{\mathrm{AMO} 14 \mathrm{~N}} \times\left[{ }^{14} \mathrm{NH}_{4}^{+}\right]-- \text {eq. }(7) \\
& \mathrm{NXR}=\mathrm{AMXNIR} \times(x /(1-x))-- \text { eq. }(8)
\end{aligned}
$$

where AMX, NXR, and AMXNIR are the $\left({ }^{14} \mathrm{~N}\right)$ fluxes of ammonium oxidation, nitrite oxidation, and reduction by anammox (Fig. 1), $k_{\mathrm{AMO} 14 \mathrm{~N}}$ is the rate constant for AMX, and $x$ is a stoichiometric ratio (increase in $\left[\mathrm{NO}_{3}^{-}\right] /$decrease in $\left[\mathrm{NO}_{2}^{-}\right]$) (Brunner et al., 2013). We omitted the two $\mathrm{N}$ transformation processes regarding denitrification (nitrate and nitrite reduction by denitrification, NAR, and DENNIR, respectively; Fig. 1) in the anammox model because of the small contributions of denitrifying bacteria to the total microbial community (Fig. S2) and the small contribution of denitrification of only $5-10 \%$ at most to the total $\mathrm{N}$ removal rate in this study (estimated by ${ }^{15} \mathrm{~N}$ tracer measurements; D. Ikeda, personal communications).
Regarding $\mathrm{NO}_{2}^{-}$;

$$
\begin{aligned}
& \mathrm{d} / \mathrm{dt}\left[{ }^{14} \mathrm{NO}_{2}^{-}\right]=-\mathrm{NXR}-\mathrm{AMXNIR} \text {--- eq. (9) } \\
& \mathrm{d} / \mathrm{dt}\left[{ }^{15} \mathrm{NO}_{2}^{-}\right]=-\left(\mathrm{R} \_ \text {NitriteN } \times \mathrm{NXR} /{ }^{15} \varepsilon_{\mathrm{NXR}}\right) \\
& -\left(\mathrm{R} \text {-NitriteN } \times \text { AMXNIR } /{ }^{15} \varepsilon_{\text {AMXNIR }}\right) \text {--- eq. (10) } \\
& \mathrm{d} / \mathrm{dt}\left[\mathrm{N}^{16} \mathrm{O}_{2}^{-}\right]=-2 \mathrm{NXR}-2 \mathrm{AMXNIR} \text {--- eq. (11) } \\
& \mathrm{d} / \mathrm{dt}\left[\mathrm{N}^{16} \mathrm{O}^{18} \mathrm{O}^{-}\right]=-\left(\mathrm{R} \text { NitriteO } \times 2 \mathrm{NXR} /{ }^{18} \mathcal{E}_{\mathrm{NXR}}\right) \\
& -\left(\mathrm{R} \_ \text {NitriteO } \times 2 \text { AMXNIR } /{ }^{18} \varepsilon_{\text {AMXNIR }}\right) \\
& -\mathrm{N}^{16} \mathrm{O}^{18} \mathrm{O}_{\text {exch_out }}^{-}+\mathrm{N}^{16} \mathrm{O}^{18} \mathrm{O}_{\text {exch_IN }}^{-} \\
& =-\left(\mathrm{R} \text { NitriteO } \times 2 \mathrm{NXR} /{ }^{18} \mathcal{E}_{\mathrm{NXR}}\right) \\
& -\left(\mathrm{R} \_ \text {NitriteO } \times 2 \text { AMXNIR } /{ }^{18} \varepsilon_{\text {AMXNIR }}\right) \\
& -k_{\text {exch }} \times\left[\mathrm{N}^{16} \mathrm{O}^{18} \mathrm{O}^{-}\right]+k_{\text {exch }} \times \mathrm{R} \_ \text {WaterO } /{ }^{18} \varepsilon_{\mathrm{EQ}} \\
& \text {--- eq. (12) }
\end{aligned}
$$

where R NitriteO, R NitrateO, R NitriteN, and R NitrateN are the ${ }^{18} \mathrm{O} /{ }^{16} \mathrm{O}$ and ${ }^{15} \mathrm{~N}^{14} \mathrm{~N}$ of $\left[\mathrm{NO}_{2}^{-}\right]$and $\left[\mathrm{NO}_{3}^{-}\right]$, respectively. R_WaterO is the $\left[{ }^{18} \mathrm{O} /{ }^{16} \mathrm{O}\right]$ of $\mathrm{H}_{2} \mathrm{O} \cdot{ }^{15} \varepsilon_{\text {NXR }}$ and ${ }^{15} \varepsilon_{\text {AMXNIR }}$ are the ${ }^{15} \mathrm{~N}$ fractionation factors of NXR and AMXNIR. ${ }^{18} \varepsilon_{\text {NXR }}$ and ${ }^{18} \varepsilon_{\text {AMXNIR }}$ are the ${ }^{18} \mathrm{O}$ fractionation factors of NXR and AMXNIR, respectively. ${ }^{18} \mathcal{E}_{\mathrm{EQ}}$, the ${ }^{18} \mathrm{O}$ fractionation factor of the equilibration between $\mathrm{NO}_{2}^{-}$and $\mathrm{H}_{2} \mathrm{O}$, was set at $13 \%$ in the present study based on the incubation temperature and $\mathrm{pH}$ (Table S1; Buchwald and Casciotti, 2013). We applied $k_{\text {exch }}$ (rate coefficient for oxygen atom

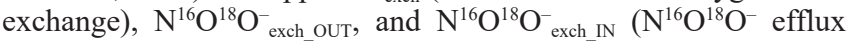
and influx regarding the $\mathrm{N}^{16} \mathrm{O}^{18} \mathrm{O}^{-}$pool, respectively) as described by $\mathrm{He}$ and $\mathrm{Bao}$ (2019) to implement oxygen atom exchange rates between $\mathrm{NO}_{2}{ }^{-}$and $\mathrm{H}_{2} \mathrm{O}$.

Regarding $\mathrm{NO}_{3}^{-}$;

$$
\begin{aligned}
\mathrm{d} / \mathrm{dt}\left[{ }^{14} \mathrm{NO}_{3}^{-}\right] & =\mathrm{NXR} \text {--- eq. }(13) \\
\mathrm{d} / \mathrm{dt}\left[{ }^{15} \mathrm{NO}_{3}^{-}\right] & =\left(\mathrm{R} \text { NitriteN } \times \mathrm{NXR} /{ }^{15} \mathcal{E}_{\mathrm{NXR}}\right)--- \text { eq. }(14) \\
\mathrm{d} / \mathrm{dt}\left[\mathrm{N}^{16} \mathrm{O}_{3}^{-}\right]=3 \mathrm{NXR}--- \text { eq. }(15) & = \\
\mathrm{d} / \mathrm{dt}\left[\mathrm{N}^{18} \mathrm{O}^{16} \mathrm{O}_{2}^{-}\right]= & \left(\mathrm{R} \text { NitriteO } \times 2 \mathrm{NXR} /{ }^{18} \varepsilon_{\mathrm{NXR}}\right) \\
& \left.+(\mathrm{R} \text { _WaterO } \times \mathrm{NXR}) /{ }^{18} \varepsilon_{\mathrm{H} 2 \mathrm{ONXR}}\right) \text {--- eq. }
\end{aligned}
$$

where ${ }^{18} \mathcal{E}_{\mathrm{H} 2 \mathrm{ONXR}}$ (assigned as $10.0 \%$; Table S1; Buchwald and Casciotti, 2010; Casciotti and Buchwald, 2012) is the ${ }^{18} \mathrm{O}$ fractionation factor for the incorporation of oxygen from $\mathrm{H}_{2} \mathrm{O}$ into $\mathrm{NO}_{3}$ during the NXR reaction (Fig. 1).

Regarding $\mathrm{NH}_{4}^{+}$;

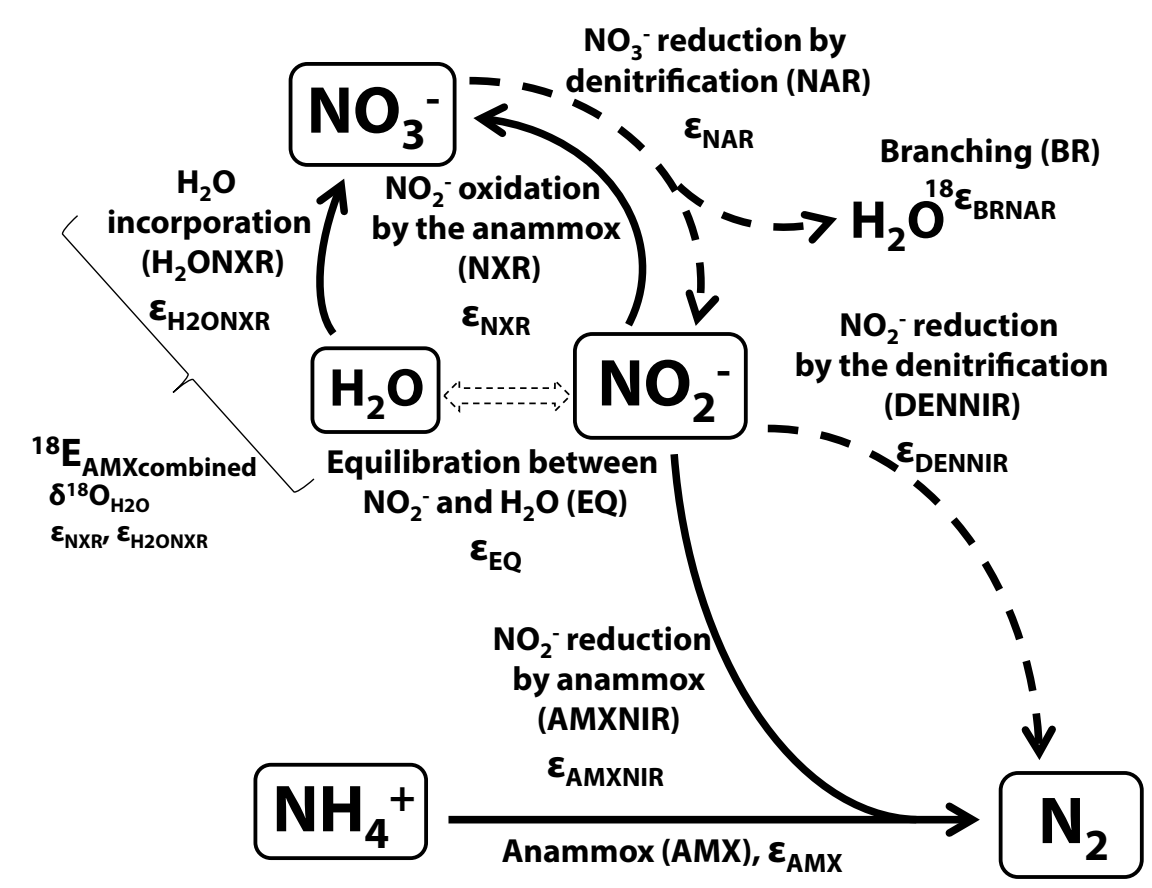

Fig. 1. Schematic of the anammox and denitrification system. Dotted arrows indicate denitrification processes that were not included in the anammox model. 
$\mathrm{d} / \mathrm{dt}\left[{ }^{14} \mathrm{NH}_{4}^{+}\right]=-\mathrm{AMX}$--- eq. (17)

$\mathrm{d} / \mathrm{dt}\left[{ }^{15} \mathrm{NH}_{4}^{+}\right]=-\left(\mathrm{R} \_\right.$AmmoniumN $\left.\times \mathrm{AMX} /{ }^{15} \varepsilon_{\mathrm{AMX}}\right)$--- eq. $(18)$

where $\mathrm{R} \_$AmmoniumN is the ${ }^{15} \mathrm{~N} /{ }^{14} \mathrm{~N}$ of $\left[\mathrm{NH}_{4}^{+}\right]$and ${ }^{15} \varepsilon_{\text {AMX }}$ is the $\mathrm{N}$ isotopic fractionation factor for $\mathrm{NH}_{4}{ }^{+}$consumption by anammox (Fig. 1).

The approximate stoichiometry of the anammox process converting $\mathrm{NO}_{2}^{-}$and $\mathrm{NH}_{4}^{+}$to $\mathrm{N}_{2}$ and $\mathrm{NO}_{3}^{-}$is as follows (Brunner et al., 2013):

$$
1.3 \mathrm{NO}_{2}^{-}+1 \mathrm{NH}_{4}^{+} \rightarrow 1 \mathrm{~N}_{2}+0.3 \mathrm{NO}_{3}^{-}+2 \mathrm{H}_{2} \mathrm{O}--- \text { eq. }
$$

However, this stoichiometry between nitrite removal and nitrate production has been reported to vary (Brunner et al., 2013). Thus, we estimated this stoichiometry $(x)$ together with $k_{\mathrm{AMO14N}}$ with concentration data, which provided the AMX, AMXNIR, and NXR fluxes used in the calculation above (eq. [7] and [8]; Table S1). After estimating $x$ and $k_{\mathrm{AMO} 14 \mathrm{~N}}$, we estimated the $k_{\text {exch }}$ of oxygen atoms between $\mathrm{H}_{2} \mathrm{O}$ and $\mathrm{NO}_{2}^{-}$(Table $\mathrm{S} 1$ ) using the curve-fitting functions for Experiments $\mathrm{A}$ and $\mathrm{B}$. In Experiment $\mathrm{C}$ with high $\delta^{18} \mathrm{O}_{\mathrm{H} 2 \mathrm{O}}$, we performed another incubation without the anammox biofilm (Fig. S3) to measure $k_{\text {exch }}$. At the same time, we estimated other isotopic fractionation factors $\left({ }^{15} \varepsilon_{\mathrm{AMXNIR}},{ }^{15} \mathcal{E}_{\mathrm{NXR}},{ }^{15} \varepsilon_{\mathrm{AMX}}\right.$, ${ }^{18} \varepsilon_{\text {AMXNIR }}$, and ${ }^{18} \varepsilon_{\mathrm{NXR}}$ ). We assigned the range from 0 to $60 \%$ (with 5 and $10 \%$ as the initial values for the curve-fitting function of BM software) to estimate isotopic fractionation factors. We considered this $60 \%$ range for the curve-fitting estimate to be reasonable because isotopic fractionation factors larger than $60 \%$ are rarely observed (Denk et al., 2017). It is important to note that curvefitting for Experiments $\mathrm{B}$ and $\mathrm{C}$ was not successfully achieved for ${ }^{18} \varepsilon_{\text {AMXNIR }}$, resulting in extremely high or low estimated values (calculated ${ }^{18} \varepsilon_{\text {AMXNIR }}$ values were 0 and $60 \%$ for Experiments $\mathrm{B}$ and $\mathrm{C}$, respectively. In addition, ${ }^{18} \varepsilon_{\mathrm{NXR}}$ (calculated as -11.2 and $-84.3 \%$ for Experiments $\mathrm{B}$ and $\mathrm{C}$, respectively) and consequently ${ }^{18} \mathrm{E}_{\mathrm{AMX} \text { combined }}$ (calculated as -4.2 and $-52.9 \%$ for Experiments $\mathrm{B}$ and $\mathrm{C}$, respectively), were not all successfully estimated for Experiments B and C. Based on these uncertainties in parameter estimations, we did not report these calculated values for Experiments $\mathrm{B}$ and $\mathrm{C}$; however, we speculate that these calculated parameter sets support ${ }^{18} \varepsilon_{\text {AMXNIR }}$ as normal and ${ }^{18} \varepsilon_{\text {NXR }}$ being inverse isotope fractionation, as discussed below for Experiment $\mathrm{A}$. The curve-fitting function ("multiple-fit" in BM software) (Macey et $a l ., 2000)$ was applied with a tolerance of $1 \times 10^{-6}$. BM codes for the anammox model for curve fittings with concentrations and isotopic data are provided in the Zenodo website (https://doi.org/ 10.5281/zenodo.3895346) and Table S2 showed the root mean square errors (RMSE) for concentrations and isotope values for the fitted model.

Simulation exercise for denitrification and anammox (the anammox-denitrification model)

We added the fluxes of denitrification (NAR and DENNIR; Fig. 3 ) to the anammox model in order for the anammox-denitrification model to simulate anammox and denitrification as follows:

Regarding $\mathrm{NO}_{2}^{-}$;

$$
\begin{aligned}
& \mathrm{d} / \mathrm{dt}\left[{ }^{14} \mathrm{NO}_{2}^{-}\right]=-\mathrm{NXR}+\mathrm{NAR}-\mathrm{DENNIR}-\mathrm{AMXNIR} \\
& \text {--- eq. (20) } \\
& \mathrm{d} / \mathrm{dt}\left[{ }^{15} \mathrm{NO}_{2}^{-}\right]=-\left(\mathrm{R} \text { NitriteN } \times \mathrm{NXR} /{ }^{15} \varepsilon_{\mathrm{NXR}}\right) \\
& +\left(\bar{R} \text { NitrateN } \times \text { NAR } /{ }^{1518} \varepsilon_{\text {NAR }}\right) \\
& -\left(\mathrm{R} \_ \text {NitriteN } \times \text { DENNIR } /{ }^{15} \varepsilon_{\text {DENNIR }}\right) \\
& -\left(R_{-} \_ \text {NitriteN } \times \text { AMXNIR } /{ }^{15} \varepsilon_{\text {AMXNIR }}\right) \\
& \text {--- eq. (21) } \\
& \mathrm{d} / \mathrm{dt}\left[\mathrm{N}^{16} \mathrm{O}_{2}^{-}\right]=-2 \mathrm{NXR}+2 \mathrm{NAR}-2 \mathrm{DENNIR}-2 \mathrm{AMXNIR} \\
& \text {--- eq. (22) }
\end{aligned}
$$

where ${ }^{1518} \mathcal{E}_{\mathrm{NAR}}$ (assigned as $15 \%$, Granger et al., 2008; Table S1) is the $\mathrm{N}$ and $\mathrm{O}$ isotopic fractionation factor of NAR (i.e., ${ }^{15} \varepsilon_{\mathrm{NAR}}=$ ${ }^{18} \varepsilon_{\mathrm{NAR}}$, Sigman et al., 2005; Granger et al., 2008; Granger et al.,
2010; Rohde et al., 2015; Osaka et al., 2018) and ${ }^{15} \varepsilon_{\text {DENNIR }}$ (assigned as 5\%, Granger and Wankel, 2016; Table S1) is the ${ }^{15} \mathrm{~N}$ fractionation factor of DENNIR.

In the case of no exchange of oxygen atoms between $\mathrm{NO}_{2}{ }^{-}$and $\mathrm{H}_{2} \mathrm{O}$,

$$
\begin{aligned}
\mathrm{d} / \mathrm{dt}\left[\mathrm{N}^{16} \mathrm{O}^{18} \mathrm{O}^{-}\right]= & -\left(\mathrm{R} \_ \text {NitriteO } \times 2 \mathrm{NXR} /{ }^{18} \mathcal{E}_{\mathrm{NXR}}\right) \\
& +\left(\mathrm{R} \text {-NitrateO } \times 2 \mathrm{NAR} /{ }^{1518} \mathcal{E}_{\text {NAR }}\right) /{ }^{18} \varepsilon_{\text {H2OBRNAR }} \\
& -\left(\mathrm{R} \text {-NitriteO } \times 2 \text { DENNIR } /{ }^{18} \varepsilon_{\text {DENNIR }}\right) \\
& -\left(\mathrm{R} \_ \text {NitriteO } \times 2 \text { AMXNIR } /{ }^{18} \varepsilon_{\text {AMXNIR }}\right) \\
\text {--- eq. (23a) } &
\end{aligned}
$$

where ${ }^{18} \varepsilon_{\text {H2OBRNAR }}$ is the ${ }^{18} \mathrm{O}$ fractionation factor for the "branching effect" (assigned as 25\%o, Casciotti and McIlvin, 2007; Table S1) during NAR (Fig. 1).

In the case of full exchange between $\mathrm{NO}_{2}{ }^{-}$and $\mathrm{H}_{2} \mathrm{O}$,

$$
\begin{aligned}
& \mathrm{d} / \mathrm{dt}\left[\mathrm{N}^{16} \mathrm{O}^{18} \mathrm{O}^{-}\right]=\mathrm{d} / \mathrm{dt}\left[\mathrm{N}^{16} \mathrm{O}_{2}^{-}\right] \times \mathrm{R} \_ \text {Oxygen } \times\left[\left(\delta^{18} \mathrm{O}_{\mathrm{NO2}-\mathrm{EQ}} / 1000\right)+1\right] \\
& \text {--- eq. }(23 \mathrm{~b})
\end{aligned}
$$

where $\delta^{18} \mathrm{O}_{\mathrm{NO} 2-\mathrm{EQ}}$ is $\delta^{18} \mathrm{O}_{\mathrm{NO} 2-}$ at the equilibrium with $\mathrm{H}_{2} \mathrm{O}\left(=\delta^{18} \mathrm{O}_{\mathrm{H} 2 \mathrm{O}}\right.$ $\left.+{ }^{18} \varepsilon_{\mathrm{EQ}}\right)$ and $\delta^{18} \mathrm{O}_{\mathrm{NO} 2-}$ is always set to $\delta^{18} \mathrm{O}_{\mathrm{NO} 2{ }_{-} \mathrm{EQ}}$.

Regarding $\mathrm{NO}_{3}^{-}$;

$$
\begin{aligned}
& \mathrm{d} / \mathrm{dt}\left[{ }^{14} \mathrm{NO}_{3}{ }^{-}\right]=\mathrm{NXR}-\mathrm{NAR} \text {--- eq. (24) } \\
& \mathrm{d} / \mathrm{dt}\left[{ }^{15} \mathrm{NO}_{3}^{-}\right]=\left(\mathrm{R} \text { NitriteN } \times \mathrm{NXR} /{ }^{15} \varepsilon_{\mathrm{NXR}}\right) \\
& -\left(\mathrm{R} \text { NitrateN } \times \text { NAR } /{ }^{1518} \varepsilon_{\mathrm{NAR}}\right)--- \text { eq. }(25) \\
& \mathrm{d} / \mathrm{dt}\left[\mathrm{N}^{18} \mathrm{O}^{16} \mathrm{O}_{2}^{-}\right]=3 \mathrm{NXR}-3 \mathrm{NAR} \text {--- eq. (26) } \\
& \mathrm{d} / \mathrm{dt}\left[\mathrm{N}^{18} \mathrm{O}^{16} \mathrm{O}_{2}^{-}\right]=\left(\mathrm{R} \_ \text {NitriteO } \times 2 \mathrm{NXR} /{ }^{18} \varepsilon_{\mathrm{NXR}}\right) \\
& \left.+\overline{(\mathrm{R}} \text { _WaterO } \times \mathrm{NXR} /{ }^{18} \varepsilon_{\mathrm{H} 2 \mathrm{ONXR}}\right) \\
& -\left(\mathrm{R} \_ \text {NitrateO } \times 3 \mathrm{NAR} /{ }^{1518} \varepsilon_{\mathrm{NAR}}\right) \text {--- eq. }
\end{aligned}
$$

We applied the estimated isotopic fractionation factors from Experiment A (Table 2) together with the reported values for fractionation factors (Fig. 3) to simulate whether the stronger contribution of anammox to denitrification alters the slope of the $\delta^{18} \mathrm{O}$ vs $\delta^{15} \mathrm{~N}$ of $\mathrm{NO}_{3}^{-}$from the denitrification slope of 1 with or without oxygen atom exchange between $\mathrm{H}_{2} \mathrm{O}$ and $\mathrm{NO}_{2}^{-}$in freshwater $\left(\delta^{18} \mathrm{O}_{\mathrm{H} 2 \mathrm{O}}=-8 \%\right)$ or seawater $(0 \%)$ environments. The $\mathrm{BM}$ code for the anammox and anammox-denitrification models is provided on the Zenodo website (https://doi.org/10.5281/zenodo.3895346).

\section{Results and Discussion}

\section{Anammox plant data}

Throughout the 17-day span of the three sampling times, the DIN concentrations and their isotopic signatures were stable (Table 1) for each reactor. Stoichiometries for the anammox process were calculated by changes in DIN concentrations between NT and ANX reactors (decreases in the concentrations of $\mathrm{NO}_{2}^{-}$and $\mathrm{NH}_{4}{ }^{+} \Delta \mathrm{NO}_{2}{ }^{-} / \Delta \mathrm{NH}_{4}{ }^{+}$, for $\mathrm{NO}_{2}{ }^{-}$ consumption, and an increase in $\mathrm{NO}_{3}^{-}$with a decrease in $\mathrm{NO}_{2}^{-}, \Delta \mathrm{NO}_{3}^{-} / \Delta \mathrm{NH}_{4}^{+}$, for $\mathrm{NO}_{3}^{-}$production). $\Delta \mathrm{NO}_{2}^{-} / \Delta \mathrm{NH}_{4}^{+}$ ranged $1.22 \sim 1.26$ and $\Delta \mathrm{NO}_{3}^{-} / \Delta \mathrm{NH}_{4}^{+}$was $0.14 \sim 0.15$, both of which were within the range for anammox reactions (1.03 to 1.32 for $\Delta \mathrm{NO}_{2}^{-} / \Delta \mathrm{NH}_{4}^{+}$and 0.14 to 0.35 for $\Delta \mathrm{NO}_{3}^{-} / \Delta \mathrm{NH}_{4}^{+}$) (Yao et al., 2015). Isaka et al. (2017) also reported that $\Delta \mathrm{NO}_{2}^{-} / \Delta \mathrm{NH}_{4}{ }^{+}$was 1.23 from this anammox plant, which indicates the appropriate performance of anammox in ANX reactor. The ammonium in the influent with a high concentration $(44.5 \mathrm{mM})$ and low $\delta^{15} \mathrm{~N}_{\mathrm{NH} 4+}(-10.4 \%$ ) was gradually consumed in the reactors with normal isotopic fractionation (i.e., with increasing $\delta^{15} \mathrm{~N}$ ), resulting in a low concentration $(1.9 \mathrm{mM})$ with high $\delta^{15} \mathrm{~N}_{\mathrm{NH} 4+}(50.2 \%)$ at final ANX reactor (Table 1). Nitrite produced in DN, BD, and NT reactors and consumed in ANX reactor had low 
Table 1. Average concentrations and isotopic compositions of DIN in the anammox plant and isotopic data from different types of WWTP

\begin{tabular}{|c|c|c|c|c|c|c|c|c|c|}
\hline Reactor & $\begin{array}{c}{\left[\mathrm{NH}_{4}^{+}\right]} \\
(\mathrm{mM})\end{array}$ & $\begin{array}{c}{\left[\mathrm{NO}_{2}^{-}\right]} \\
(\mathrm{mM})\end{array}$ & $\begin{array}{c}{\left[\mathrm{NO}_{3}^{-}\right]} \\
(\mathrm{mM})\end{array}$ & $\begin{array}{c}\delta^{15} \mathrm{~N}_{\mathrm{NH} 4+} \\
(\% 0)\end{array}$ & $\begin{array}{c}\delta^{15} \mathrm{~N}_{\mathrm{NO} 2-} \\
(\% 0)\end{array}$ & $\begin{array}{c}\delta^{18} \mathrm{O}_{\mathrm{NO} 2-} \\
(\% 0)\end{array}$ & $\begin{array}{c}\delta^{15} \mathrm{~N}_{\mathrm{NO} 3-} \\
(\% 0)\end{array}$ & $\begin{array}{c}\delta^{18} \mathrm{O}_{\mathrm{NO} 3-} \\
(\% 0)\end{array}$ & \\
\hline Influent & $44.5(0.1)$ & $0(0)$ & $0(0)$ & $-10.4(0.2)$ & n.d. & n.d. & n.d. & n.d. & \\
\hline $\mathrm{DN}$ & $40.7(0.2)$ & $0.2(0)$ & $0(0)$ & $-8.4(0.2)$ & $-27.3(0.4)$ & $4.7(0.2)$ & n.d. & n.d. & \\
\hline $\mathrm{BD}$ & $32.8(0.7)$ & $7.7(0.6)$ & $0(0)$ & $0.6(0.9)$ & $-38.8(0.8)$ & $4.3(0.2)$ & n.d. & n.d. & \\
\hline NT & $18.7(0.4)$ & $21.2(0.3)$ & $0(0)$ & $19.2(0.7)$ & $-28.2(0.4)$ & $4.5(0.1)$ & n.d. & n.d. & \\
\hline ANX & $1.9(0.5)$ & $0.4(0)$ & $2.5(0)$ & $50.2(1.4)$ & $-21.6(0.4)$ & $3.3(0.3)$ & $9.3(0.4)$ & $2.7(0.2)$ & \\
\hline WWTP type ${ }^{\#}$ & & & & & & & & & Reference \\
\hline CAS & & & & 0 to 36 & & & 13 to 15 & -1 to 0 & Tumendelger et al., 2014 \\
\hline $\mathrm{A}_{2} \mathrm{O}$ & & & & & & & $8.1^{*}$ & $-4.5^{*}$ & Toyoda et al., 2011 \\
\hline Preliminary & & & & & & & $11.5(3.1)^{* *}$ & $4.9(4.2)^{* *}$ & Archana et al., 2016 \\
\hline Primary & & & & & & & $14.8(3.9)^{* *}$ & $8.6(3.4)^{* *}$ & Archana et al., 2016 \\
\hline CEPT & & & & & & & $10.6(4.9)^{* *}$ & $-2.1(3.6)^{* *}$ & Archana et al., 2016 \\
\hline Secondary & & & & & & & $12.5(4.3)^{* *}$ & $3.8(2.4)^{* *}$ & Archana et al., 2016 \\
\hline Tertiary & & & & & & & $90.7(83.9)^{* *}$ & $87.7(90.6)^{* *}$ & Archana et al., 2016 \\
\hline
\end{tabular}

Means from three sampling times with standard errors (in parentheses) are shown. n.d.: not determined

* Data from the sampling point closest to the outlet to the river

** Means from several WWTP with standard deviations (in parentheses) are shown.

\# CAS: Conventional activated sludge, $\mathrm{A}_{2} \mathrm{O}$ : Anaerobic-Anoxic-Oxic treatment, CEPT: Chemically Enhanced Primary Treatment

Table 2. Isotopic fractionation factors during anammox (\%o)

\begin{tabular}{|c|c|c|c|c|}
\hline \multirow{2}{*}{ Open system } & \multicolumn{3}{|c|}{ Anammox Plant (This study) } & \multirow{2}{*}{$\begin{array}{c}\text { Reported values } \\
\text { Kobayashi et al., (2019) }\end{array}$} \\
\hline & 20150428 & 20150507 & 20150512 & \\
\hline${ }^{15} \Delta_{\text {AMXNIR }}$ & 11.8 & 12.0 & 12.4 & $5.9 \sim 29.5$ \\
\hline${ }^{15} \Delta_{\mathrm{NXR}}$ & -30.4 & -31.1 & -31.3 & $-30.1 \sim-45.3$ \\
\hline${ }^{15} \Delta_{\mathrm{AMX}}$ & 34.0 & 34.8 & 34.4 & $30.9 \sim 32.7$ \\
\hline${ }^{18} \mathrm{E}_{\text {AMXcombined }} *$ & -3.8 & -2.5 & -3.2 & $-1.5 \sim-12.1$ \\
\hline \multirow{2}{*}{ Closed system } & \multicolumn{3}{|c|}{ Batch incubations (This study) } & Reported values \\
\hline & Experiment A & Experiment B & Experiment $\mathrm{C}$ & Brunner et al., (2013) \\
\hline${ }^{15} \varepsilon_{\mathrm{AMXNIR}}$ & 13.7 & 21.8 & 15.6 & 16.0 \\
\hline${ }^{15} \varepsilon_{\mathrm{NXR}}$ & -77.8 & -65.9 & -71.1 & -31.1 \\
\hline${ }^{15} \varepsilon_{\mathrm{AMX}}$ & 32.5 & 25.4 & 19.3 & $23.5 \sim 29.1$ \\
\hline${ }^{18} \mathrm{E}_{\text {AMXcombined }} *$ & -10.4 & n.d. & n.d. & n.d. \\
\hline${ }^{18} \varepsilon_{\mathrm{AMXNIR}} * *$ & 3.1 & n.d. & n.d. & n.d. \\
\hline${ }^{18} \varepsilon_{\mathrm{NXR}} * *$ & -20.6 & n.d. & n.d. & n.d. \\
\hline
\end{tabular}

$*:{ }^{18} \varepsilon_{\mathrm{NXR}} \times 2 / 3+{ }^{18} \varepsilon_{\mathrm{H} 2 \mathrm{ONXR}} / 3$ (Kobayashi et al., 2019)

$* *$ : assuming ${ }^{18} \varepsilon_{\mathrm{EQ}}=1.013,{ }^{18} \varepsilon_{\mathrm{H} 2 \mathrm{ONXR}}=1.010$ (Table S2)

$\delta^{15} \mathrm{~N}_{\mathrm{NO} 2-}$ values (-38.8 to $-21.6 \%$ ) and relatively stable $\delta^{18} \mathrm{O}_{\mathrm{NO} 2-}$ values (3.3 to $4.7 \%$; Table 1$)$. Nitrate was not produced before ANX reactor and $\delta^{15} \mathrm{~N}_{\mathrm{NO} 3-}(9.3 \%)$ was higher than $\delta^{15} \mathrm{~N}_{\mathrm{NO} 2-}(-21.6 \%)$, with no significant difference between $\delta^{18} \mathrm{O}_{\mathrm{NO} 3-}$ and $\delta^{18} \mathrm{O}_{\mathrm{NO} 2-}$ in ANX (Table 1). In comparisons with the isotopic data for other types of WWTP (Table 1 ), we found that the lower $\delta^{18} \mathrm{O}_{\mathrm{NO3}-}$ and higher $\delta^{15} \mathrm{~N}_{\mathrm{NH} 4+}$ from the anammox plant was useful for tracking the fate of $\mathrm{N}$ derived from the anammox wastewater plant.

The calculated ${ }^{15} \Delta_{\mathrm{AMX}}$ was large $(34.0 \sim 34.8 \%$; Table 2$)$, which was similar to the reported value for anammox (30.9 $\sim 32.7 \%$; Kobayashi et al., 2019) and to the isotope effect for aerobic ammonia oxidization $(29.6 \pm 4.9 \%$; Denk et al., 2017). The two $\mathrm{NO}_{2}^{-}$consumption pathways in the ANX reactor had different ${ }^{15} \mathrm{~N}$ fractionation; normal (positive), large ${ }^{15} \Delta_{\text {AMXNIR }}\left(11.8 \sim 12.4 \%\right.$ ), and inverse (negative) ${ }^{15} \Delta_{\text {NXR }}$ $(-30.4 \sim-31.3 \%$ ), which fell within reported values (Kobayashi et al., 2019) (Table 2). The present results confirmed an inverse ${ }^{15} \mathrm{~N}$ effect during anaerobic $\mathrm{NO}_{2}^{-}$oxidation to $\mathrm{NO}_{3}^{-}$, as previously reported (Brunner et al., 2013; Kobayashi et al., 2019) for aerobic $\mathrm{NO}_{2}^{-}$oxidation to $\mathrm{NO}_{3}^{-}$(Casciotti,
2009; Buchwald and Casciotti, 2010). Similarly, the small and negative apparent "combined" ${ }^{18} \mathrm{O}$ fractionation for ammonium oxidization by $\mathrm{NO}_{2}-\left(-2.5 \sim-3.8 \% ;{ }^{18} \mathrm{E}_{\mathrm{AMx} \text { combined }}\right)$ also fell within the reported range of -1.5 to $-12 \%$ o (Kobayashi et al., 2019) (Table 2). The negative ${ }^{18} \mathrm{E}_{\mathrm{AmX}}$ combined values reported here and by Kobayashi et al. (2019) during $\mathrm{NO}_{3}^{-}$ production in anammox agree with the inverse ${ }^{18} \mathrm{O}$ fractionation for aerobic nitrite oxidation to $\mathrm{NO}_{3}^{-}$(Casciotti, 2009; Buchwald and Casciotti, 2010).

\section{Incubation experiments}

In all experiments, $\left[\mathrm{NH}_{4}^{+}\right]$and $\left[\mathrm{NO}_{2}^{-}\right]$concurrently decreased as $\left[\mathrm{NO}_{3}^{-}\right]$increased (Fig. 2a, b, and c). Averaged stoichiometries during anammox were $1.29,1.51$, and 1.48 for $\Delta \mathrm{NO}_{2}^{-} / \Delta \mathrm{NH}_{4}^{+}$and $0.16,0.17$, and 0.21 for $\Delta \mathrm{NO}_{3}^{-}$/ $\Delta \mathrm{NH}_{4}{ }^{+}$in Experiments A, B, and C, respectively (Fig. 2a, b, and $\mathrm{c}$ ). These results were more consistent in their stoichiometry than previous findings with the same anammox bacterium (1.00 to 2.12 for $\Delta \mathrm{NO}_{2}^{-} / \Delta \mathrm{NH}_{4}^{+}$and 0.10 to 0.37 for $\Delta \mathrm{NO}_{3}{ }^{-} / \Delta \mathrm{NH}_{4}^{+}$; Ali et al., 2015). The estimated values of $x$, $k_{\mathrm{AMO} 14 \mathrm{~N}}$, and $k_{\text {exch }}$ were shown in Table S1. The estimated $x$ 

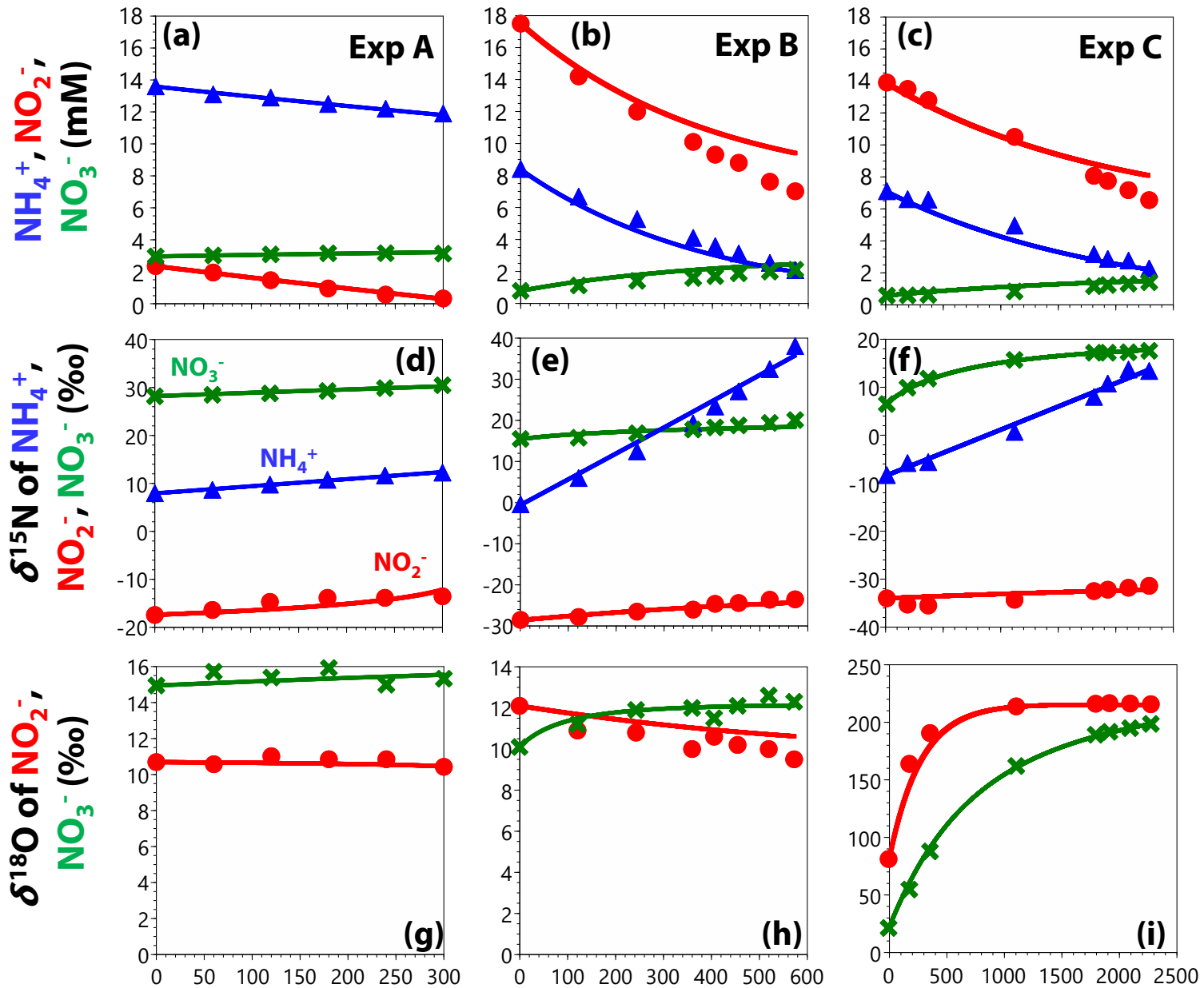

Incubation time ( $\mathrm{min})$

Fig. 2. Concentrations and isotopic signatures of inorganic $\mathrm{N}$ in incubation experiments. The lines represent changes in the concentrations and isotopic signatures estimated by the curve-fitting of rate constants (for concentrations, upper panels) and ${ }^{15} \mathrm{~N}$ and ${ }^{18} \mathrm{O}$ fractionation factors (for $\delta^{15} \mathrm{~N}$ and $\delta^{18} \mathrm{O}$ values, middle and lower panels). The root mean square error (RMSE) for each fitting was shown in Table S1.

values $(0.13$ to 0.21 ; Table $\mathrm{S} 1)$ were similar to reported values (0.15 to 0.48; Brunner et al., 2013), and $k_{\text {exch }}$ values were negligible (Table S1). The anammox rates based on $\mathrm{NH}_{4}^{+}$ consumption were $39.7,61.7$, and $12.4 \mu \mathrm{M}$ (g-S.S.) ${ }^{-1} \mathrm{~h}^{-1}$ for Experiments A, B and C, respectively.

$\delta^{15} \mathrm{~N}_{\mathrm{NH} 4+}, \delta^{15} \mathrm{~N}_{\mathrm{NO2}-}$, and $\delta^{15} \mathrm{~N}_{\mathrm{NO} 3-}$ increased as $\left[\mathrm{NH}_{4}{ }^{+}\right]$and $\left[\mathrm{NO}_{2}{ }^{-}\right]$decreased during anammox (Fig. 2d, e, and f). In contrast, $\delta^{18} \mathrm{O}_{\mathrm{NO} 2-}$ and $\delta^{18} \mathrm{O}_{\mathrm{NO} 3-}$ did not change in Experiment A (Fig. $2 \mathrm{~g}$ ), while $\delta^{18} \mathrm{O}_{\mathrm{NO} 3-}$ increased by $\sim 2 \%$ and $\delta^{18} \mathrm{O}_{\mathrm{NO} 2-}$ decreased by $\sim 3 \%$ in Experiment B (Fig. 2h). In Experiment $\mathrm{C}$ with the high $\delta^{18} \mathrm{O}$ of $\mathrm{H}_{2} \mathrm{O}(229 \%), \delta^{18} \mathrm{O}_{\mathrm{NO} 2-}$ and $\delta^{18} \mathrm{O}_{\mathrm{NO} 3-}$ rapidly increased (Fig. $2 \mathrm{i}$ ). $\delta^{18} \mathrm{O}_{\mathrm{NO2}-}$ also rapidly increased in the negative control experiment without the biomass (Fig. S3). The isotope exchange between $\mathrm{NO}_{2}^{-}$and $\mathrm{NO}_{3}^{-}$needs to be taken into consideration (Brunner et al., 2013 ) when the rapid and large changes in $\delta^{15} \mathrm{~N}$ and $\delta^{18} \mathrm{O}$ at the beginning of the incubation are observed. Since we did not observe such a marked change in $\delta^{15} \mathrm{~N}$ and $\delta^{18} \mathrm{O}$, indicating isotope exchange (Fig. 2), we did not include isotope exchange between $\mathrm{NO}_{2}{ }^{-}$and $\mathrm{NO}_{3}{ }^{-}$in the present study.

${ }^{15} \varepsilon_{\text {AMX }}$ values were calculated as $32.5,25.4$, and $19.3 \%$ for Experiments A, B, and C, respectively (Table 2, Fig. 2d, $\mathrm{e}$, and $\mathrm{f}$ ). These ${ }^{15} \varepsilon_{\mathrm{AMX}}$ values were similar to previously reported values $(23.5 \sim 29.1 \%$ ) for Kuenenia stuttgartiensis in batch incubation experiments (Brunner et al., 2013). ${ }^{15} \varepsilon_{\text {AMXNIR }}$ values were estimated to be $13.7,21.8$, and $15.6 \%$ (Table 2, Fig. 2d, e, and f), while ${ }^{18} \varepsilon_{\text {AMXNIR }}$ values were 3.1, 0 and $60.0 \%$ (Table 2, Fig. 2d, e, and f) for Experiments A, $\mathrm{B}$ and $\mathrm{C}$, respectively. Although ${ }^{18} \varepsilon_{\text {AMXNIR }}$ values in Experiments $\mathrm{B}$ and $\mathrm{C}$ were not successfully measured (Table 2; see the Methods), estimated ${ }^{15} \varepsilon_{\text {AMXNIR }}$ values were consistent with the ${ }^{15} \mathrm{~N}$ values reported for $\mathrm{NO}_{2}^{-}$reduction by $\mathrm{Cu}-\mathrm{NIR}$ coded by the nirK gene ( $22 \pm 2$ and $2 \pm 2 \%$ ) (Martin and Casciotti, 2016). The similarity in these values was attributed to the Cu-NIR of "Candidatus Jettenia" with the nirK gene (Hira et al., 2012; Ali et al., 2015), the dominant microbe in incubation experiments (Fig. S2).

In addition to normal isotopic fractionation, we estimated ${ }^{15} \mathrm{~N}$ and ${ }^{18} \mathrm{O}$ fractionation factors during anaerobic nitrite oxidization to $\mathrm{NO}_{3}{ }^{-}$of $-77.8 \%$ for ${ }^{15} \varepsilon_{\mathrm{NXR}}$ and $-20.6 \%$ for ${ }^{18} \varepsilon_{\mathrm{NXR}}$ (Table 2, Fig. 2g, h, and i) in Experiment A. Although we also estimated ${ }^{15} \mathrm{~N}$ and ${ }^{18} \mathrm{O}$ fractionation factors of -65.9 and $-71.1 \%$ for ${ }^{15} \varepsilon_{\mathrm{NXR}}$ and -11.2 and $-84.3 \%$ for ${ }^{18} \varepsilon_{\mathrm{NXR}}$ for Experiments $\mathrm{B}$ and $\mathrm{C}$, respectively, ${ }^{18} \varepsilon_{\mathrm{NXR}}$ values for these experiments were not precisely measured. The large inverse ${ }^{15} \mathcal{E}_{\mathrm{NXR}}$ is consistent with the reported value with $K$. 
stuttgartiensis (-31.1 $\pm 3.9 \%$; Brunner et al., 2013), as well as aerobic nitrite oxidation to $\mathrm{NO}_{3}{ }^{-}$by nitrite-oxidizing bacteria $(-12.8 \pm 1.5 \%$; Casciotti, 2009). Regarding oxygen, although only ${ }^{18} \varepsilon_{\mathrm{NXR}}$ in Experiment $\mathrm{A}$ was successfully assessed, the estimated ${ }^{18} \varepsilon_{\text {NXR }}$ value was negative and close to the inverse ${ }^{18} \mathrm{O}$ fractionation factors for aerobic nitrite oxidization to $\mathrm{NO}_{3}^{-}$by nitrite-oxidizing bacteria $(-10$ to $-1 \%$; Buchwald and Casciotti, 2010).

\section{Simulation for denitrification and anammox}

We developed an anammox-denitrification model with the estimated isotopic fractionation factors (from Experiment A; Table 2) and reported values (Fig. 3) to clarify whether anammox induces a deviation in $\delta^{18} \mathrm{O}_{\mathrm{NO}-}$ vs $\delta^{15} \mathrm{~N}_{\mathrm{NO} 3-}$ from the denitrification slope of 1 (i.e., $\Delta(15,18)$; defined as $\left(\delta^{15} \mathrm{~N}-\delta^{15} \mathrm{~N}_{\text {initial }}\right)-\left({ }^{18} \mathcal{\varepsilon} /{ }^{15} \varepsilon\right)\left(\delta^{18} \mathrm{O}-\delta^{18} \mathrm{O}_{\text {initial }}\right)$, where ${ }^{18} \varepsilon /{ }^{15} \varepsilon$ is the ratio of isotopic fractionation for $\mathrm{O}$ and $\mathrm{N}$ during denitrification, respectively, and assigned as 1 ; see the inset in Fig. 4a; Sigman et al., 2005). Each simulation was run until more than $25 \%$ of $\mathrm{NO}_{2}^{-}$was consumed. In the case of denitrification in which AMX / NAR is equal to 0 (indicating no anammox), $\delta^{18} \mathrm{O}_{\mathrm{NO} 3-}$ vs $\delta^{15} \mathrm{~N}_{\mathrm{NO} 3-}$ was set to

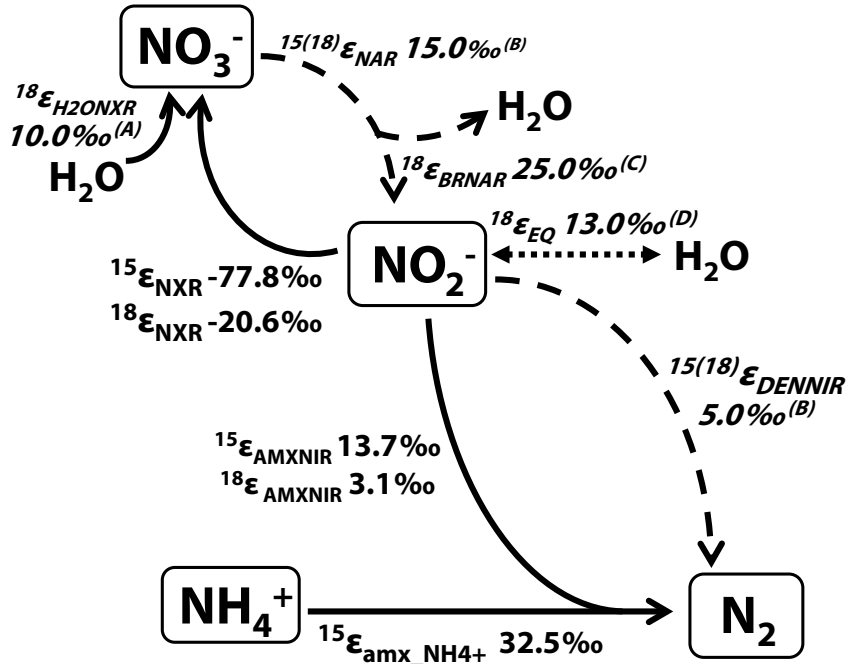

Fig. 3. Isotopic fractionation factors applied in the anammoxdenitrification simulation model. These factors were from Experiment A or previous studies; (A) Buchwald and Casciotti, 2010; (B) Granger and Wankel, 2016; (C) Casciotti et al., 2002; (D) Buchwald and Casciotti, 2013.

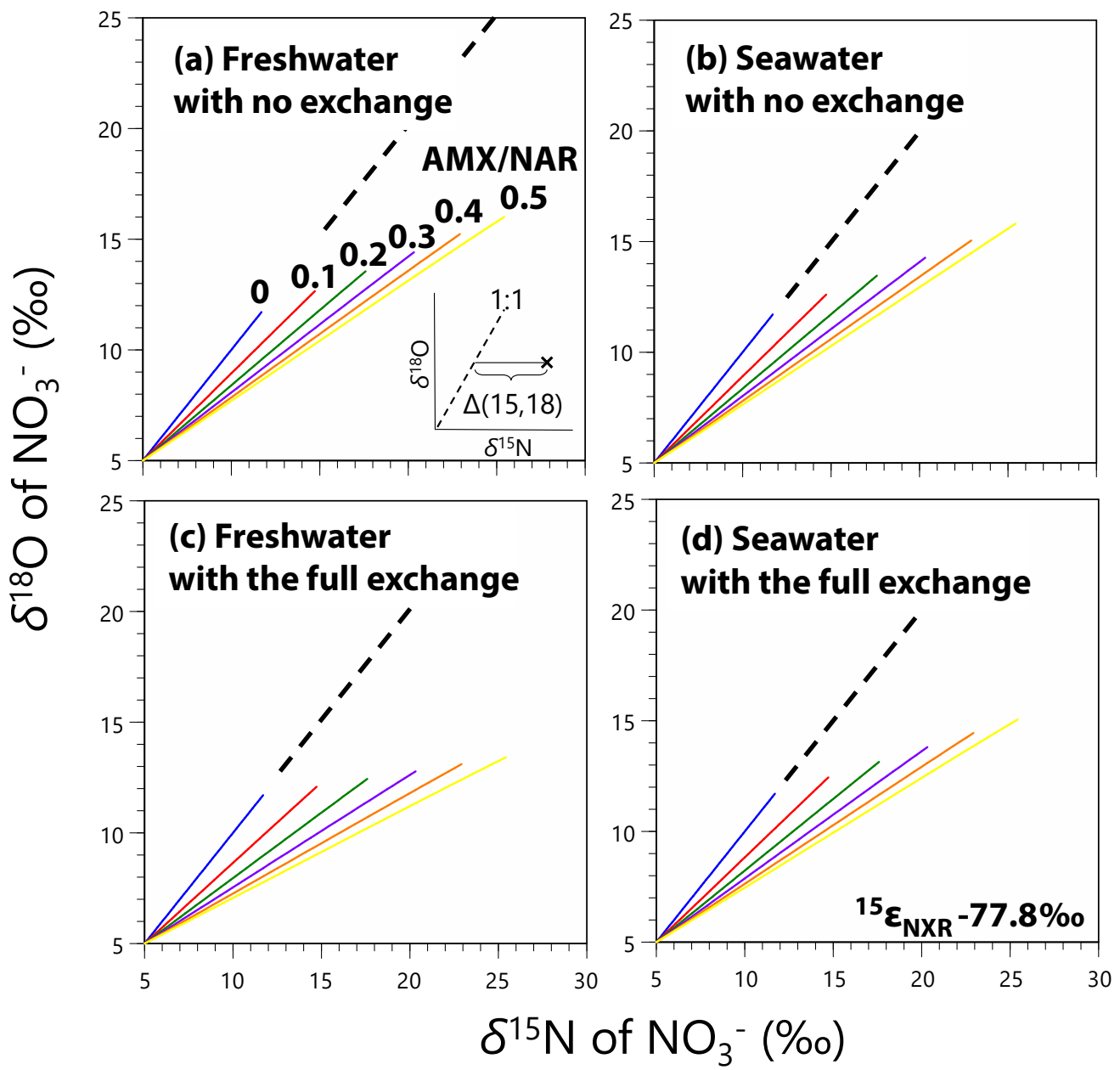

Fig. 4. Results from the anammox-denitrification model for variable ratios of anammox (AMX) and denitrification (NAR), and with or without oxygen atom exchange between water and $\mathrm{NO}_{2}^{-}$. The simulation was run with ${ }^{15} \varepsilon_{\mathrm{NXR}}=-77.8 \%$ (Table 2) until more than $25 \%$ of the initial $\mathrm{NO}_{2}$ pool was consumed; however, $\mathrm{NO}_{2}{ }^{-}$consumption in simulations with the same run times varied according to the different AMX / NAR ratios. The end point of each simulation run was not important, whereas the slope of each run was. The dotted line in each panel illustrated the denitrification slope (1:1) and the inset in Fig. 4a shows $\Delta(15,18)$ in the $\delta^{15} \mathrm{~N}$ and $\delta^{18} \mathrm{O}$ space. 

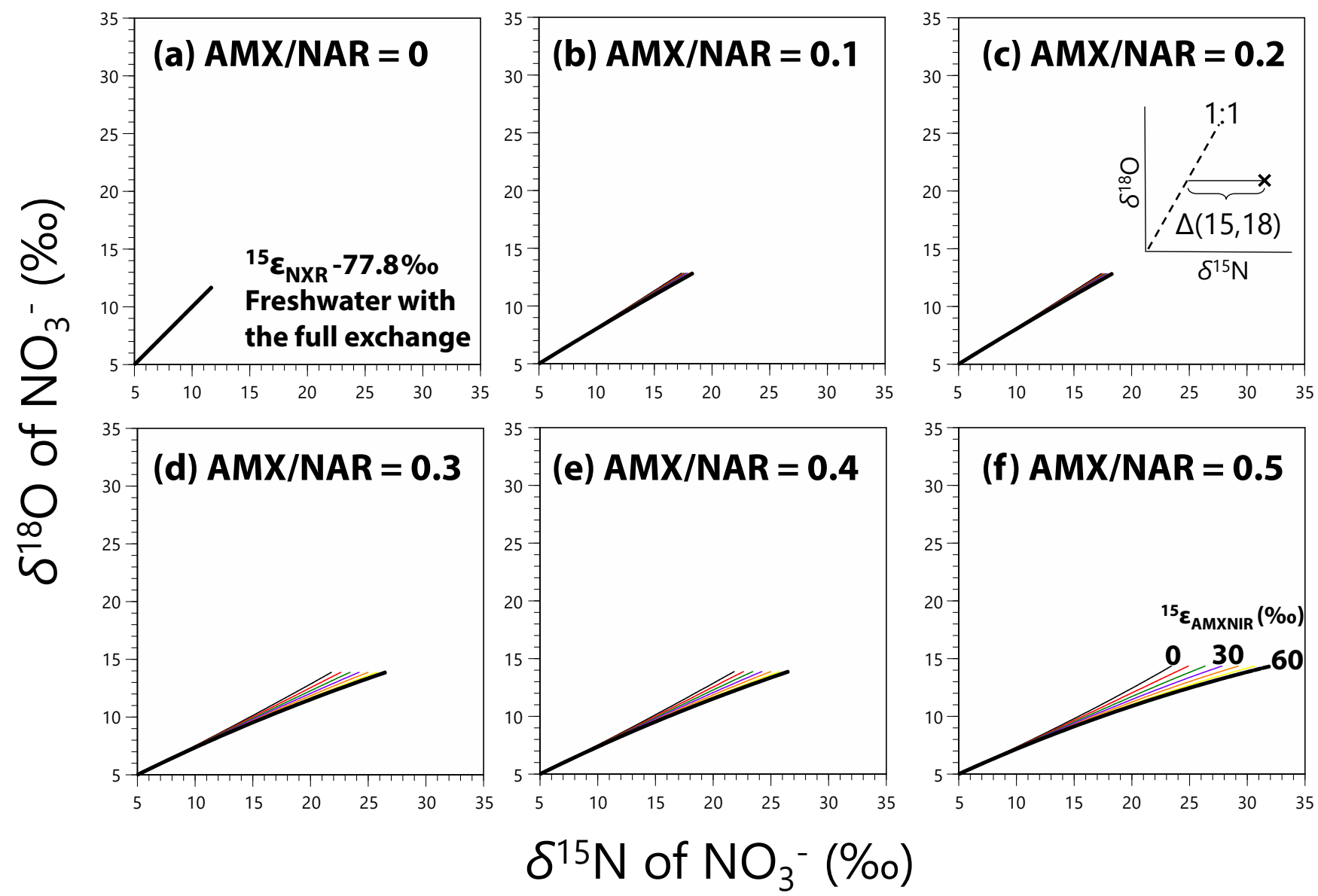

Fig. 5. Results of the anammox-denitrification model for variable ANX / NAR ratios with variable ${ }^{15} \varepsilon_{\text {AmXNIR }}$ values with the full oxygen atom exchange between water (freshwater with $\delta^{18} \mathrm{O}_{\mathrm{H} 2 \mathrm{O}}=-8 \%$ ) and $\mathrm{NO}_{2}^{-}$. The simulation was run with ${ }^{15} \mathcal{E}_{\mathrm{NXR}}=-77.8 \%$ (Table 2) until more than $25 \%$ of the initial $\mathrm{NO}_{2}^{-}$pool was consumed; however, $\mathrm{NO}_{2}^{-}$consumption in simulations with the same run times varied according to the different AMX / NAR ratios. The end point of each simulation run was not important, whereas the slope of each run was crucial. The inset in Fig. $5 \mathrm{c}$ shows $\Delta(15,18)$ in the $\delta^{15} \mathrm{~N}$ and $\delta^{18} \mathrm{O}$ space.

show a slope of 1 (the dotted lines in Fig. 4a, d, c, and d). As reported in previous studies (Casciotti and Buchwald, 2012; Granger and Wankel, 2016; He and Bao, 2019), larger anammox rates (larger AMX / NAR) induced greater offsets (larger $\Delta[15,18]$ ) from the $1: 1$ relationship between $\delta^{18} \mathrm{O}_{\mathrm{NO} 3-}$ and $\delta^{15} \mathrm{~N}_{\mathrm{NO} 3-}$ in all cases (Fig. $4 \mathrm{a}, \mathrm{b}, \mathrm{c}$, and d). The effect of oxygen atom exchange was small, but obvious (Fig. 4c for freshwater and Fig. 4d for seawater) with a larger offset with the exchange. Although the present results revealed that $\Delta(15,18)$ is a sensitive parameter for the occurrence of anammox, its usefulness diminishes with smaller ${ }^{15} \varepsilon_{\mathrm{NXR}}$ values (-31.1\%o, Table 2 and Fig. S4), indicating the sensitivity of $\Delta(15,18)$ against ${ }^{15} \varepsilon_{\mathrm{NXR}}$ (i.e., the stronger ${ }^{15} \varepsilon_{\mathrm{NXR}}$, the larger $\Delta[15,18])$. To elucidate the relationship between $\Delta(15,18), \mathrm{AMX} / \mathrm{NAR}$, and isotopic fractionation factors, we simulated the $\delta^{18} \mathrm{O}_{\mathrm{NO} 3}$ and $\delta^{15} \mathrm{~N}_{\mathrm{NO} 3-}$ trajectories along with the different AMX / NAR ratios and ${ }^{15} \varepsilon_{\text {AMXNXR }}$ (Fig. 5 with ${ }^{15} \varepsilon_{\mathrm{NXR}}=-77.8 \%$ and Fig. S5 with $-31.1 \%$ ). Similar to ${ }^{15} \varepsilon_{\mathrm{NXR}}$, stronger ${ }^{15} \varepsilon_{\mathrm{AMXNXR}}$ resulted in larger $\Delta(15,18)$; however, $\Delta(15,18)$ depended on AMX / NAR, ${ }^{15} \varepsilon_{\text {AMXNXR, and }}$ ${ }^{15} \varepsilon_{\mathrm{NXR}}$ (Fig. 5 and S5). Therefore, a simple comparison of $\Delta(15,18)$ data does not permit quantitative estimations of AMX / NAR because $\Delta(15,18)$ increases with $\mathrm{NO}_{2}^{-}$and $\mathrm{NO}_{3}^{-}$consumption whenever anammox is active (AMX / NAR $>0$; Fig. 4 and 5$)$ and $\Delta(15,18)$ levels strongly depend on many parameters, including ${ }^{15} \varepsilon_{\mathrm{AMXNXR}}$ and ${ }^{15} \varepsilon_{\mathrm{NXR}}$. Although more information on isotopic fractionation factors is needed for quantitative interpretations due to the sensitivity of $\Delta(15,18)$, our simulation exercise revealed that $\Delta(15$, 18 ), the offset from the $1: 1$ relationship between $\delta^{15} \mathrm{~N}$ and $\delta^{18} \mathrm{O}$, may be useful for detecting NXR (nitrite oxidation) in denitrifying systems in both freshwater and seawater.

Besides NXR, some chemolithoautotrophic (e.g., sulfidedependent) denitrification with auxiliary Nap $\mathrm{NO}_{3}^{-}$reductase may exhibit a 2:1 rather than $1: 1$ relationship between $\delta^{15} \mathrm{~N}$ and $\delta^{18} \mathrm{O}$, resulting in an offset from the $1: 1$ relationship (Frey et al., 2014). Although this non-respiratory pathway (i.e., Nap $\mathrm{NO}_{3}{ }^{-}$reduction) is not considered to be a major environmental sink for $\mathrm{NO}_{3}^{-}$(Granger and Wankel, 2016), and, thus, was not included in our models, it is worthwhile considering this autotrophic denitrification as a driver of the offset in a sulfide-rich environment in which anammox may be inhibited (Jensen et al., 2008) and sulfidedependent denitrification enhanced.

\section{Conclusion}

We estimated ${ }^{15} \mathrm{~N}$ and ${ }^{18} \mathrm{O}$ fractionation factors during anammox. The inverse ${ }^{15} \mathrm{~N}$ effects for NXR (and possibly inverse $\mathrm{O}$ isotope effects) may induce an offset from the 
denitrification trajectory (1:1 relationship between $\delta^{15} \mathrm{~N}$ and $\delta^{18} \mathrm{O}$ of $\left.\mathrm{NO}_{3}^{-}, \Delta[15,18]\right)$. In practice, $\Delta(15,18)$ may be evaluated with time-course samplings or short incubation studies to investigate the occurrence of anammox, similar to denitrification. This technique will be advantageous because of its potential in evaluations of the quantitative contribution in situ of anammox versus denitrification. Although the detection and quantification of functional genes in denitrification and anammox may be readily performed, difficulties are associated with detecting the in situ occurrence of denitrification and anammox. Although the isotopic fractionation factors used also need to be considered, $\Delta(15,18)$ is a promising parameter to complement molecular data and the results from laboratory incubation experiments in the study of anammox.

\section{Acknowledgements}

We thank T. Makita, A. Koba, and E. Murata for helping with sampling and the chemical analysis, and K. Casciotti and M. McIlvin for the calibration of our in-house $\mathrm{NO}_{2}{ }^{-}$standards. We also appreciate E. Hobbie for fruitful discussions and English editing. This study was financially supported by research funds from JSPS (26252020, 16H02524, 17H06297, and 18H04138).

\section{References}

Ali, M., Oshiki, M., Awata, T., Isobe, K., Kimura, Z., Yoshikawa, H., et al. (2015) Physiological characterization of anaerobic ammonium oxidizing bacterium "Candidatus Jettenia caeni". Environ Microbiol 17: 2172-2189.

Amano, T., Yoshinaga, I., Okada, K., Yamagishi, T., Ueda, S., Obuchi, A., et al., (2007) Detection of anammox activity and diversity of anammox bacteria-related 16S rRNA genes in coastal marine sediment in Japan. Microbes Environ 22: 232-242.

Archana, A., Luo, L., Shuh-Ji, K., Thibodeau, B., and Baker, D.M. (2016) Variations in nitrate isotope composition of wastewater effluents by treatment type in Hong Kong. Mar Pollut Bull 111: 143152.

Barford, C., Montoya, J., Altabet, M., and Mitchell, R. (2017) Steadystate oxygen isotope effects of $\mathrm{N}_{2} \mathrm{O}$ production in Paracoccus denitrificans. Microb Ecol 74: 507-509.

Blackmer, A.M., and Bremner, J.M. (1977) Nitrogen isotope discrimination in denitrification of nitrate in soils. Soil Biol Biochem 9: 73-77.

Böttcher, J., Strebel, O., Voerkelius, S., and Schmidt, H.L. (1990) Using isotope fractionation of nitrate-nitrogen and nitrate-oxygen for evaluation of microbial denitrification in a sandy aquifer. J Hydrol (Amsterdam, Neth) 114: 413-424.

Bourbonnais, A., Lehmann, M.F., Hamme, R.C., Manning, C.C., and Juniper, S.K. (2013) Nitrate elimination and regeneration as evidenced by dissolved inorganic nitrogen isotopes in Saanich Inlet, a seasonally anoxic fjord. Mar Chem 157: 194-207.

Bourbonnais, A., Letscher, R.T., Bange, H.W., Échevin, V., Larkum, J., Mohn, J., et al. (2017) $\mathrm{N}_{2} \mathrm{O}$ production and consumption from stable isotopic and concentration data in the Peruvian coastal upwelling system. Global Biogeochem Cycles 31: 678-698.

Brunner, B., Contreras, S., Lehmann, M.F., Matantseva, O., Rollog, M., Kalvelage, T., et al. (2013) Nitrogen isotope effects induced by anammox bacteria. Proc Natl Acad Sci U S A 110: 18994-18999.

Bryan, B.A., Shearer, G., Skeeters, J.L., and Kohl, D.H. (1983) Variable expression of the nitrogen isotope effect associated with denitrification of nitrite. $J$ Biol Chem 258: 8613-8617.

Buchwald, C., and Casciotti, K.L. (2010) Oxygen isotopic fractionation and exchange during bacterial nitrite oxidation. Limnol Oceanogr 55: 1064-1074.

Buchwald, C., and Casciotti, K.L. (2013) Isotopic ratios of nitrite as tracers of the sources and age of oceanic nitrite. Nat Geosci 6: 308313.
Casciotti, K.L., Sigman, D.M., Galanter Hastings, M., Böhlke, J.K., and Hilkert, A. (2002) Measurement of the oxygen isotopic composition of nitrate in seawater and freshwater using the denitrifier method. Anal Chem 74: 4905-4912.

Casciotti, K.L., Böhlke, J.K., Mcllvin, M.R., Mroczkowski, S.J., and Hannon, J.E. (2007) Oxygen isotopes in nitrite: Analysis, calibration, and equilibration. Anal Chem 79: 2427-2436.

Casciotti, K.L., and McIlvin, M.R. (2007) Isotopic analyses of nitrate and nitrite from reference mixtures and application to Eastern Tropical North Pacific waters. Mar Chem 107: 184-201.

Casciotti, K.L., Trull, T.W., Glover, D.M., and Davies, D. (2008) Constraints on nitrogen cycling at the subtropical North Pacific Station ALOHA from isotopic measurements of nitrate and particulate nitrogen. Deep-Sea Res 55: 1661-1672.

Casciotti, K.L. (2009) Inverse kinetic isotope fractionation during bacterial nitrite oxidation. Geochim Cosmochim Acta 73: 20612076.

Casciotti, K.L., and Buchwald, C. (2012) Insights on the marine microbial nitrogen cycle from isotopic approaches to nitrification. Front Microbiol 3:356.

Casciotti, K.L. (2016a) Nitrogen and oxygen isotopic studies of the marine nitrogen cycle. Ann Rev Mar Sci 8: 379-407.

Casciotti, K.L. (2016b) Nitrite isotopes as tracers of marine $\mathrm{N}$ cycle processes. Philos Trans R Soc, A 374: 20150295.

Chien, S.H., Shearer, G., and Kohl, D.H. (1977) The nitrogen isotope effect associated with nitrate and nitrite loss from waterlogged soils. Soil Sci Soc Am J 41: 63-69.

Dähnke, K., and Thamdrup, B. (2016) Isotope fractionation and isotope decoupling during anammox and denitrification in marine sediments. Limnol Oceanogr 61: 610-624.

Dalsgaard, T., Canfield, D.E., Petersen, J., Thamdrup, B., and AcuñaGonzález, J. (2003) $\mathrm{N}_{2}$ production by the anammox reaction in the anoxic water column of Golfo Dulce, Costa Rica. Nature 422: 606608.

Denk, T.R.A., Mohn, J., Decock, C., Lewicka-Szczebak, D., Harris, E., Butterbach-Bahl, K., et al. (2017) The nitrogen cycle: A review of isotope effects and isotope modeling approaches. Soil Biol Biochem 105: 121-137.

Fang, Y., Koba, K., Makabe, A., Takahashi, C., Zhu, W., Hayashi, T., et al. (2015) Microbial denitrification dominates nitrate losses from forest ecosystems. Proc Natl Acad Sci U S A 112: 1470-1474.

Fry, B. (2006) Stable Isotope Ecology. New York, NY: Springer-Verlag.

Frey, C., Hietanen, S., Jürgens, K., Labrenz, M., and Voss, M. (2014) N and $\mathrm{O}$ isotope fractionation in nitrate during chemolithoautotrophic denitrification by Sulfurimonas gotlandica. Environ Sci Technol 48: 13229-13237.

Granger, J., Sigman, D.M., Lehmann, M.F., and Tortell, P.D. (2008) Nitrogen and oxygen isotope fractionation during dissimilatory nitrate reduction by denitrifying bacteria. Limnol Oceanogr 53: 2533-2545.

Granger, J., and Sigman, D.M. (2009) Removal of nitrite with sulfamic acid for nitrate $\mathrm{N}$ and $\mathrm{O}$ isotope analysis with the denitrifier method. Rapid Commun Mass Spectrom 23: 3753-3762.

Granger, J., Sigman, D.M., Rohde, M.M., Maldonado, M.T., and Tortell, P.D. (2010) $\mathrm{N}$ and $\mathrm{O}$ isotope effects during nitrate assimilation by unicellular prokaryotic and eukaryotic plankton cultures. Geochim Cosmochim Acta 74: 1030-1040.

Granger, J., and Wankel, S.D. (2016) Isotopic overprinting of nitrification on denitrification as a ubiquitous and unifying feature of environmental nitrogen cycling. Proc Natl Acad Sci U S A 113: E6391-E6400.

Hamasaki, K., Shishikura, R., Suzuki, S., Shiozaki, T., Ogawa, H., Nakamura, T., et al. (2018) Distribution and phylogeny of anaerobic ammonium-oxidizing (anammox) bacteria in the water column of the central Pacific Ocean. Deep-Sea Res 156: 60-67.

Hamersley, M.R., Lavik, G., Woebken, D., Rattray, J.E., Lam, P., Hopmans, E.C., et al. (2007) Anaerobic ammonium oxidation in the Peruvian oxygen minimum zone. Limnol Oceanogr 52: 923-933.

He, Y., and Bao, H. (2019) Predicting high-dimensional isotope relationships from diagnostic fractionation factors in systems with diffusional mass transfer. ACS Earth Space Chem 3: 120-128.

Hira, D., Toh, H., Migita, C.T., Okubo, H., Nishiyama, T., Hattori, M., et al. (2012) Anammox organism KSU-1 expresses a NirK-type copper-containing nitrite reductase instead of a NirS-type with cytochrome $\mathrm{cd}_{1}$. FEBS Lett 586: 1658-1663. 
Holmes, R.M., Aminot, A., Kerouel, R., Hooker, B.A., and Peterson, B.J. (1999) A simple and precise method for measuring ammonium in marine and freshwater ecosystems. Can J Fish Aquat Sci 56: 18011908.

Houlton, B.Z., Sigman, D.M., and Hedin, L.O. (2006) Isotopic evidence for large gaseous nitrogen losses from tropical rainforests. Proc Natl Acad Sci U S A 103: 8745-8750.

Houlton, B.Z., and Bai, E. (2009) Imprint of denitrifying bacteria on the global terrestrial biosphere. Proc Natl Acad Sci U S A 106: 2171321716

Isaka, K., Kimura, Y., Matsuura, M., Osaka, T., and Tsuneda, S. (2017) First full-scale nitritation-anammox plant using gel entrapment technology for ammonia plant effluent. Biochem Eng $J$ 122: 115122.

Jaeschke, A., Hopmans, E.C., Wakeham, S.G., Schouten, S., and Damsté, J.S.S. (2007) The presence of ladderane lipids in the oxygen minimum zone of the Arabian Sea indicates nitrogen loss through anammox. Limnol Oceanogr 52: 780-786.

Jensen, M.M., Kuypers, M.M.M., Lavik, G., and Thamdrup, B. (2008) Rates and regulation of anaerobic ammonium oxidation and denitrification in the Black Sea. Limnol Oceanogr 53: 23-36.

Karsh, K.L., Granger, J., Kritee, K., and Sigman, D.M. (2012) Eukaryotic assimilatory nitrate reductase fractionates $\mathrm{N}$ and $\mathrm{O}$ isotopes with a ratio near unity. Environ Sci Technol 46: 5727-5735.

Kawanishi, T., Hayashi, Y., Kihou, N., Yoneyama, T., and Ozaki, Y. (1993) Dispersion effect on the apparent nitrogen isotope fractionation factor associated with denitrification in soil; Evaluation by a mathematical model. Soil Biol Biochem 25: 349-354.

Koba, K., Tokuchi, N., Wada, E., Nakajima, T., and Iwatsubo, G. (1997) Intermittent denitrification: The application of a ${ }^{15} \mathrm{~N}$ natural abundance method to a forested ecosystem. Geochim Cosmochim Acta 61: 5043-5050.

Koba, K., Fang, Y., Mo, J., Zhang, W., Lu, X., Liu, L., et al. (2012) The ${ }^{15} \mathrm{~N}$ natural abundance of the $\mathrm{N}$ lost from an $\mathrm{N}$-saturated subtropical forest in southern China. $J$ Geophys Res Biogeosci 117: G02015.

Kobayashi, K., Makabe, A., Yano, M., Oshiki, M., Kindaichi, T., Casciotti, K.L., et al. (2019) Dual nitrogen and oxygen isotope fractionation during anaerobic ammonium oxidation by anammox bacteria. ISME J 13: 2426-2436.

Kritee, K., Sigman, D.M., Granger, J., Ward, B.B., Jayakumar, A., and Deutsch, C. (2012) Reduced isotope fractionation by denitrification under conditions relevant to the ocean. Geochim Cosmochim Acta 92: $243-259$.

Kuypers, M.M.M., Silekers, A.O., Lavik, G., Schmid, M., Jøorgensen, B.B., Kuenen, J.G., et al. (2003) Anaerobic ammonium oxidation by anammox bacteria in the Black Sea. Nature 422: 608-611.

Lam, P., Lavik, G., Jensen, M.M., De Van Vossenberg, J., Schmid, M., Woebken, D., et al. (2009) Revising the nitrogen cycle in the Peruvian oxygen minimum zone. Proc Natl Acad Sci U S A 106: 4752-4757.

Lehmann, M.F., Reichert, P., Bernasconi, S.M., Barbieri, A., and McKenzie, J.A. (2003) Modelling nitrogen and oxygen isotope fractionation during denitrification in a lacustrine redox-transition zone. Geochim Cosmochim Acta 67: 2529-2542.

Lennon, E.F.E., and Houlton, B.Z. (2017) Coupled molecular and isotopic evidence for denitrifier controls over terrestrial nitrogen availability. ISME J 11: 727-740.

Macey, R., Oster, G., and Zahnley, T. (2000) Berkeley Madonna User's Guide. Version 8.0. Berkeley, CA. University of California, Depaetment of Molecular and Cellular Biology. URL http:// www.berkeleymadonna.com

Mariotti, A., Germon, J.C., Hubert, P., Kaiser, P., Letolle, R., Tardieux, A., et al. (1981) Experimental determination of nitrogen kinetic isotope fractionation: Some principles; illustration for the denitrification and nitrification processes. Plant Soil 62: 413-430.

Mariotti, A., Germon, J.C., and Leclerc, A. (1982) Nitrogen isotope fractionation associated with the $\mathrm{NO}_{2}^{-} \rightarrow \mathrm{N}_{2} \mathrm{O}$ step of denitrification in soils. Can J Soil Sci 62: 227-241.

Mariotti, A., Landreau, A., and Simon, B. (1988) ${ }^{15} \mathrm{~N}$ isotope biogeochemistry and natural denitrification process in groundwater: Application to the chalk aquifer of northern France. Geochim Cosmochim Acta 52: 1869-1878.

Martin, T.S., and Casciotti, K.L. (2016) Nitrogen and oxygen isotopic fractionation during microbial nitrite reduction. Limnol Oceanogr 61: $1134-1143$
McIlvin, M.R., and Altabet, M.A. (2005) Chemical conversion of nitrate and nitrite to nitrous oxide for nitrogen and oxygen isotopic analysis in freshwater and seawater. Anal Chem 77: 5589-5595.

McIlvin, M.R., and Casciotti, K.L. (2006) Method for the analysis of $\delta^{18} \mathrm{O}$ in water. Anal Chem 78: $2377-2381$.

Miyajima, T., Yoshimizu, C., Tsuboi, Y., Tanaka, Y., Tayasu, I., Nagata, T., et al. (2009) Longitudinal distribution of nitrate $\delta^{15} \mathrm{~N}$ and $\delta^{18} \mathrm{O}$ in two contrasting tropical rivers: Implications for instream nitrogen cycling. Biogeochemistry 95: 243-260.

Osaka, K., Nakajima, Y., Suzuki, K., Eguchi, S., and Katou, H. (2018) Nitrogen and oxygen isotope enrichment factors of nitrate at different denitrification rates in an agricultural soil. Soil Sci Plant Nutr (Abingdon, $U$ K) 64: 558-565.

Ostrom, N.E., Hedin, L.O., Von Fischer, J.C., and Robertson, G.P. (2002) Nitrogen transformations and $\mathrm{NO}_{3}^{-}$removal at a soil-stream interface: A stable isotope approach. Ecol Appl 12: 1027-1043.

Peters, B.D., Lam, P.J., and Casciotti, K.L. (2018) Nitrogen and oxygen isotope measurements of nitrate along the US GEOTRACES Eastern Pacific Zonal Transect (GP16) yield insights into nitrate supply, remineralization, and water mass transport. Mar Chem 201: 137150.

Prokopenko, M.G., Hammond, D.E., Berelson, W.M., Bernhard, J.M., Stott, L., and Douglas, R. (2006) Nitrogen cycling in the sediments of Santa Barbara basin and Eastern Subtropical North Pacific: Nitrogen isotopes, diagenesis and possible chemosymbiosis between two lithotrophs (Thioploca and Anammox) - "riding on a glider". Earth Planet Sci Lett 242: 186-204.

Prokopenko, M.G., Hirst, M.B., De Brabandere, L., Lawrence, D.J.P., Berelson, W.M., Granger, J., et al. (2013) Nitrogen losses in anoxic marine sediments driven by Thioploca-anammox bacterial consortia. Nature 500: 194-198.

Rohde, M.M., Granger, J., Sigman, D.M., and Lehmann, M.F. (2015) Coupled nitrate $\mathrm{N}$ and $\mathrm{O}$ stable isotope fractionation by a natural marine plankton consortium. Front Mar Sci 2: 28.

Sigman, D.M., Casciotti, K.L., Andreani, M., Barford, C., Galanter, M. and Böhlke, J.K. (2001) A bacterial method for the nitrogen isotopic analysis of nitrate in seawater and freshwater. Anal Chem 73: 41454153

Sigman, D.M., Robinson, R., Knapp, A.N., van Geen, A., McCorkle, D.C., Brandes, J.A., et al. (2003) Distinguishing between water column and sedimentary denitrification in the Santa Barbara Basin using the stable isotopes of nitrate. Geochem, Geophys, Geosyst 4 1040 .

Sigman, D.M., Granger, J., DiFiore, P.J., Lehmann, M.M., Ho, R., Cane, G., et al. (2005) Coupled nitrogen and oxygen isotope measurements of nitrate along the eastern North Pacific margin. Global Biogeochem Cycles 19: GB4022.

Thuan, N.C., Koba, K., Yano, M., Makabe, A., Kinh, C.T., Terada, A., et al. (2018) $\mathrm{N}_{2} \mathrm{O}$ production by denitrification in an urban river: evidence from isotopes, functional genes, and dissolved organic matter. Limnology 19: 115-126.

Toyoda, S., Suzuki, Y., Hattori, S., Yamada, K., Fujii, A., Yoshida, N., et al. (2011) Isotopomer analysis of production and consumption mechanisms of $\mathrm{N}_{2} \mathrm{O}$ and $\mathrm{CH}_{4}$ in an advanced wastewater treatment system. Environ Sci Technol 45: 917-922.

Tumendelger, A., Toyoda, S., and Yoshida, N. (2014) Isotopic analysis of $\mathrm{N}_{2} \mathrm{O}$ produced in a conventional wastewater treatment system operated under different aeration conditions. Rapid Commun Mass Spectrom 28: 1883-1892.

Wang, A., Fang, Y., Chen, D., Phillips, O., Koba, K., Zhu, W., et al. (2018) High nitrogen isotope fractionation of nitrate during denitrification in four forest soils and its implications for denitrification rate estimates. Sci Total Environ 633: 1078-1088.

Wenk, C.B., Zopfi, J., Blees, J., Veronesi, M., Niemann, H., and Lehmann, M.F. (2014) Community $\mathrm{N}$ and $\mathrm{O}$ isotope fractionation by sulfide-dependent denitrification and anammox in a stratified lacustrine water column. Geochim Cosmochim Acta 125: 551-563.

White, M.E., Rafter, P.A., Stephens, B.M., Wankel, S.D., and Aluwihare, L.I. (2019) Recent increases in water column denitrification in the seasonally suboxic bottom waters of the Santa Barbara Basin. Geophys Res Lett 46: 6786-6795.

Yao, Z., Lu, P., Zhang, D., Wan, X., Li, Y., and Peng, S. (2015) Stoichiometry and kinetics of the anaerobic ammonium oxidation (Anammox) with trace hydrazine addition. Bioresour Technol 198: $70-76$. 